$1 / 2 / 24 \lg 6050$

\title{
Radiological Dose Assessment Related to Management of Naturally Occurring Radioactive Materials Generated by the Petroleum Industry
}

Environmental Assessment Division Argonne National' Laboratory

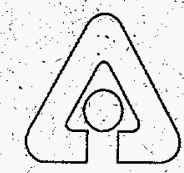

Operated by The University of Chicago, under Contract W-31-109-Eng-38, for the

United States Department of Energy 


\section{Argonne National Laboratory}

Argonne National Laboratory, with facilities in the states of Illinois and Idaho, is owned by the United States Government, and operated by the University, of Chicago under the provisions of a contract with the Department of Energy.

This technical report is a product of Argonne's Environmental Assessment Division. For information on the division's scientific and engineering activities, contact:

Director, Environmental Assessment Division

Argonne National Laboratory

Argonne, Illinois 60439-4815

Telephone (630) 252-3107

Publishing support senvices were provided by Argonne's Information and Publishing Division (for more information, see IPD's home page: nttp://www.ipd.anl.gov/).

\section{Disclaimer}

This report was prepared as an account of work sponsored by an agency of the United States Government. Neither the United States Government nor any agency thereof, nor any of their employees, makes any warranty: express or implied; or assumes any legal liability or responsibility for the accuracy, completeness, or usefulness of any information, apparatus, product, or process disclosed, or represents that its use would not infringe privately owned rights. Reference herein to any specific commercial product, process, or service by trade name, trademark, manufacturer, or otherwise, does not necessarily constitute or imply its endorsement, recommendation, or favoring by the United States Government or any. agency thereof. The views and opinions of authors expressed herein do not necessarily state or reflect those of the United States Government or any agency thereof.

Reproduced directly from the best available copy.

Available to DOE and DOE contractors from the Office of Scientific and Technical Information, P.O. Box 62, Oak Ridge, TN 37831; prices available from (423) $576-8401$ :

Available to the public from the National Technical information Service, U.S. Department of Commerce, 5285. Port Royal Road, Springfield, VA 22161. 


\section{Radiological Dose Assessment Related to Management of Naturally Occurring Radioactive Materials Generated by the Petroleum Industry}

by K.P. Smith, D.L. Blunt, G.P. Williams, and C.L. Tebes*

Environmental Assessment Division

Argonne National Laboratory, 9700 South Cass Avenue, Argonne, Illinois 60439

September 1996

Work sponsored by the United States Department of Energy,

Office of Policy

"Tebes is affiliated with the University of Illinois.

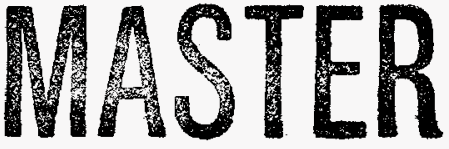




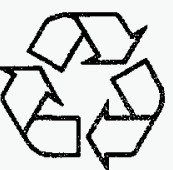

This report is printed on recycled paper. 


\section{DISCLAMMER}

Portions of this document may be illegible in electronic image products. Images are produced from the best available original document. 


\section{CONTENTS}

ACKNOWLEDGMENTS $\ldots \ldots \ldots \ldots \ldots \ldots \ldots \ldots \ldots \ldots \ldots \ldots \ldots \ldots \ldots$ vii

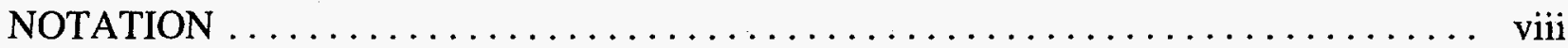

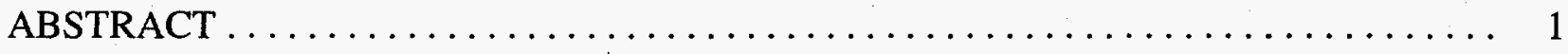

SUMMARY $\ldots \ldots \ldots \ldots \ldots \ldots \ldots \ldots \ldots \ldots \ldots \ldots \ldots \ldots \ldots \ldots \ldots \ldots \ldots \ldots$

1 INTRODUCTION $\ldots \ldots \ldots \ldots \ldots \ldots \ldots \ldots \ldots \ldots \ldots \ldots \ldots \ldots \ldots \ldots$

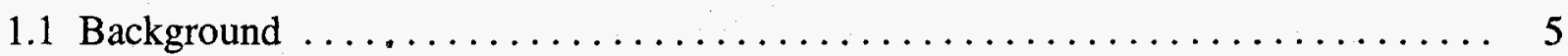

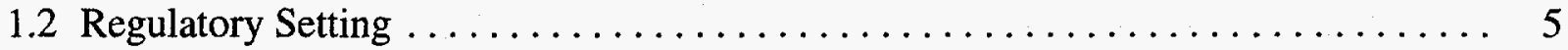

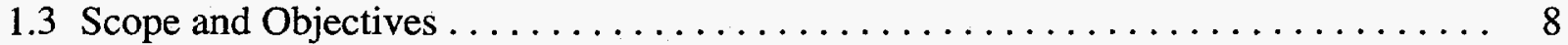

2 CHARACTERIZATION OF NORM WASTES $\ldots \ldots \ldots \ldots \ldots \ldots \ldots \ldots \ldots \ldots \ldots$

2.1 Source Term Characterization $\ldots \ldots \ldots \ldots \ldots \ldots \ldots \ldots \ldots \ldots \ldots \ldots \ldots \ldots$

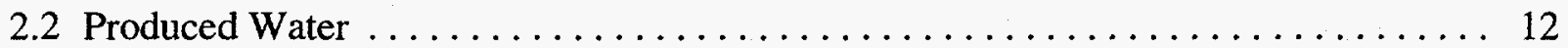

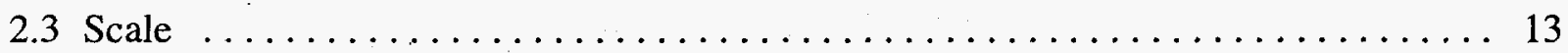

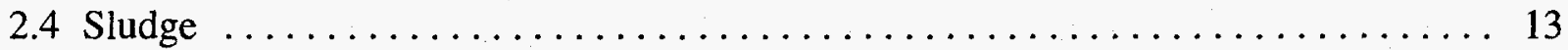

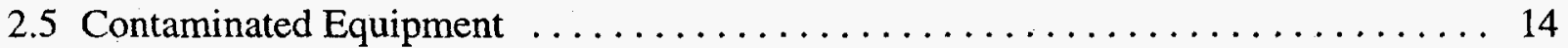

3 NORM MANAGEMENT AND DISPOSAL OPTIONS $\ldots \ldots \ldots \ldots \ldots \ldots \ldots$

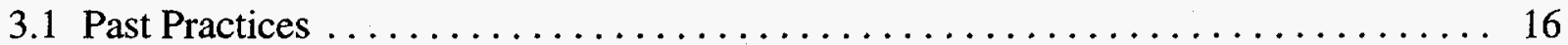

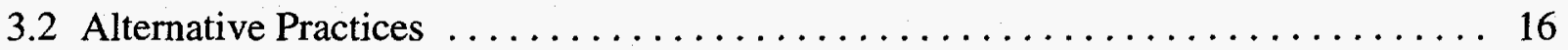

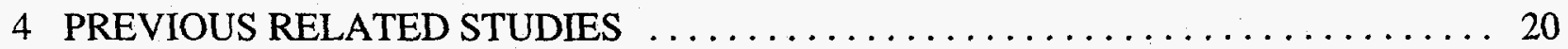

5 EQUIPMENT CLEANING FACILITIES $\ldots \ldots \ldots \ldots \ldots \ldots \ldots \ldots \ldots \ldots \ldots \ldots$

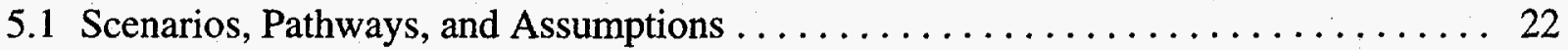

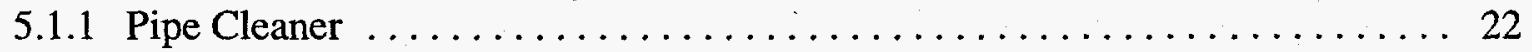

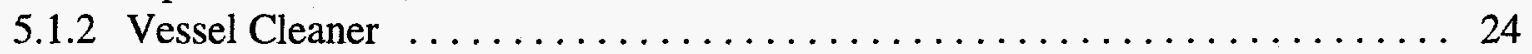

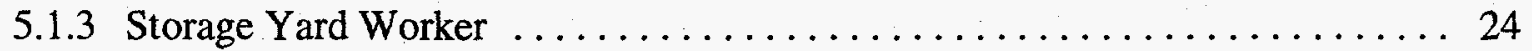

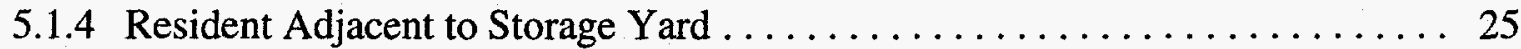

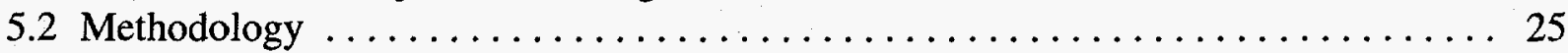

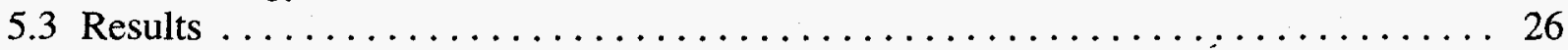

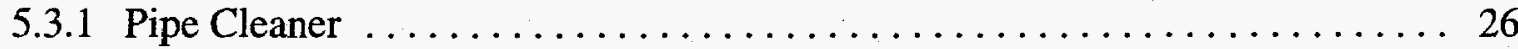

5.3 .2 Vessel Cleaner . . . . . . . . . . . . . . . . . . . . . . . . . 29

5.3 .3 Storage Yard Worker . . . . . . . . . . . . . . . . . . . . . 29

5.3 .4 Resident Adjacent to Storage Yard $\ldots \ldots \ldots \ldots \ldots \ldots \ldots \ldots \ldots \ldots$ 


\section{CONTENTS (Cont.)}

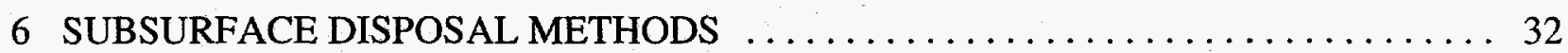

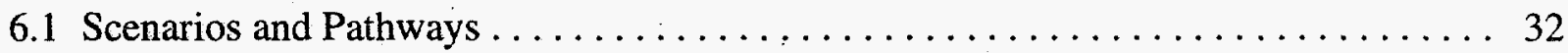

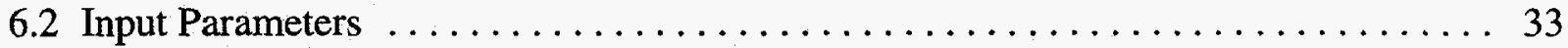

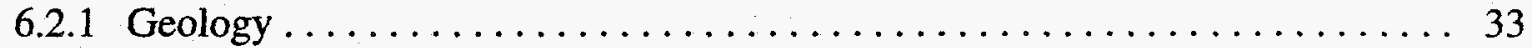

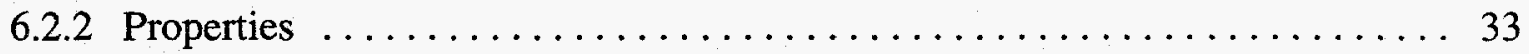

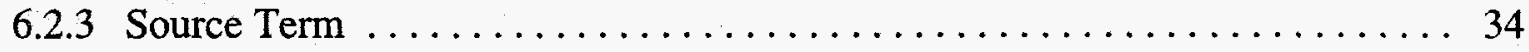

6.2 .4 Casing Failure and Receptor Locations $\ldots \ldots \ldots \ldots \ldots \ldots \ldots \ldots \ldots \ldots \ldots$

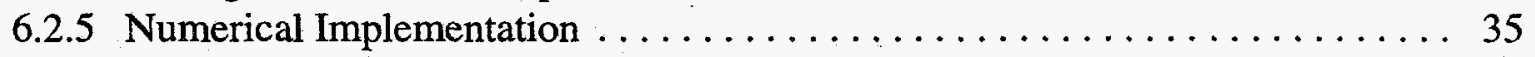

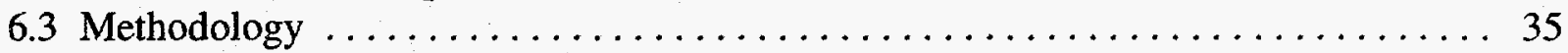

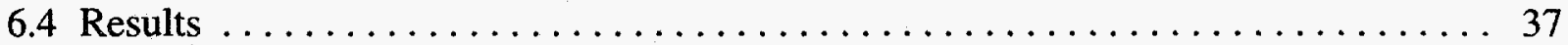

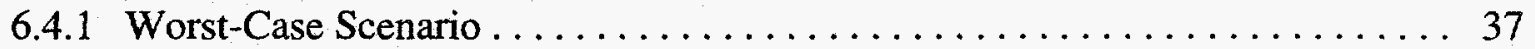

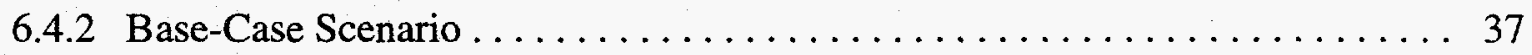

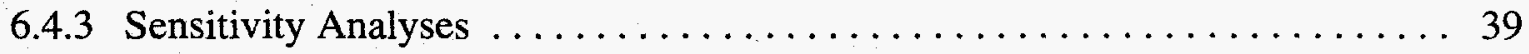

7 LANDSPREADING WITH DILUTION $\ldots \ldots \ldots \ldots \ldots \ldots \ldots \ldots \ldots \ldots \ldots \ldots \ldots \ldots \ldots \ldots$

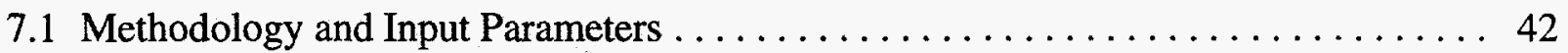

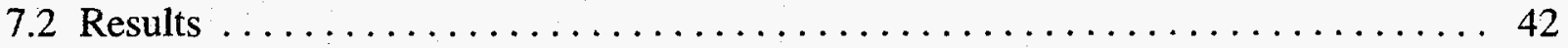

8 SCRAP METAL RECYCLING OF CONTAMINATED EQUIPMENT $\ldots \ldots \ldots \ldots .44$

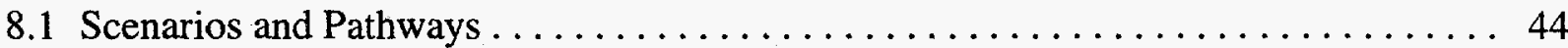

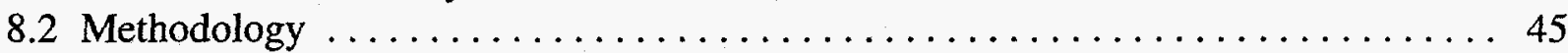

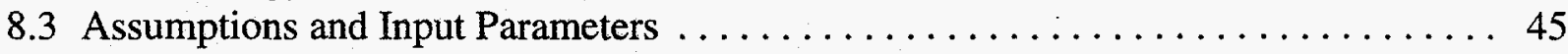

8.3.1 Scrap Metal Concentration $\ldots \ldots \ldots \ldots \ldots \ldots \ldots \ldots \ldots \ldots \ldots \ldots \ldots, \ldots \ldots \ldots$

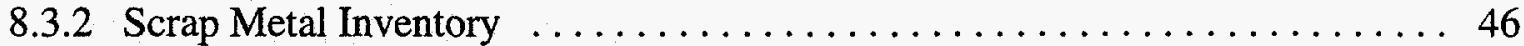

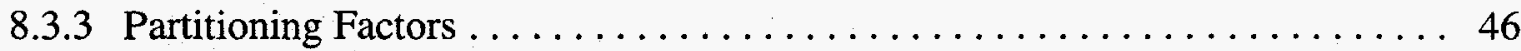

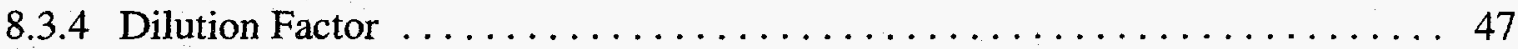

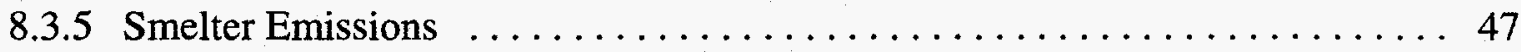

8.3.6 Shallow Burial of Contaminated Equipment $\ldots \ldots \ldots \ldots \ldots \ldots \ldots \ldots 47$

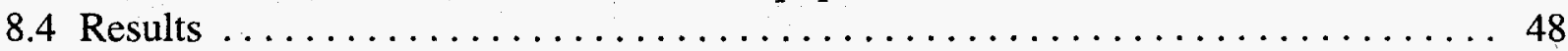

8.4.1 Doses Associated with Recycling Scenarios $\ldots \ldots \ldots \ldots \ldots \ldots \ldots \ldots 48$

8.4.2 Doses to the Public from Smelter Emissions . . . . . . . . . . . . . . . 48

8.4.3 Doses from Shallow Burial of Contaminated Equipment $\ldots \ldots \ldots \ldots \ldots .48$

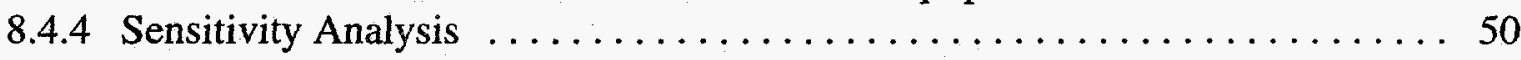

9 CONCLUSIONS AND RECOMMENDATIONS $\ldots \ldots \ldots \ldots \ldots \ldots \ldots \ldots \ldots$

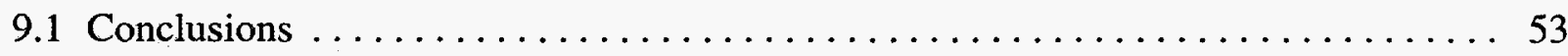

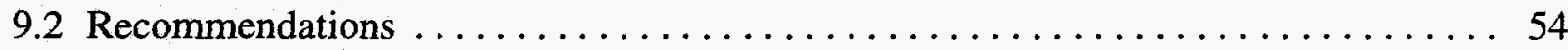




\section{CONTENTS (Cont.)}

10 REFERENCES

\section{FIGURES}

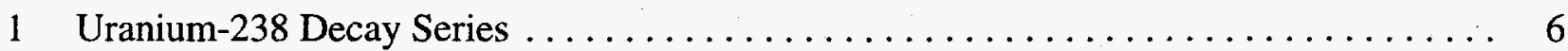

2 Thorium-232 Decay Series $\ldots \ldots \ldots \ldots \ldots \ldots \ldots \ldots \ldots \ldots \ldots \ldots \ldots \ldots$

3 NORM Disposal and Management Alternatives $\ldots \ldots \ldots \ldots \ldots \ldots \ldots \ldots$

4 Pipe Cleaner Scenario Shield Thickness Sensitivity $\ldots \ldots \ldots \ldots \ldots \ldots \ldots \ldots$

5 Pipe Cleaner Scenario Receptor Distance Sensitivity $\ldots \ldots \ldots \ldots \ldots \ldots \ldots \ldots$

6 Storage Yard Worker Scenario Shield Thickness Sensitivity . . . . . . . . . . 30

7 Storage Yard Worker Scenario Receptor Distance Sensitivity . . . . . . . . . . 30

8 Mesh Used in the SWIFT II Model $\ldots \ldots \ldots \ldots \ldots \ldots \ldots \ldots \ldots \ldots \ldots \ldots \ldots \ldots \ldots \ldots$

9 Total Dose over Time Summed over All Pathways for Landspreading with Dilution . . . 43

10 Comparison of Pathways for Landspreading with Dilution $\ldots \ldots \ldots \ldots \ldots \ldots \ldots$

11 Sensitivity Analysis for the Slag Worker (constraining scenario) $\ldots \ldots \ldots \ldots \ldots 2$

\section{TABLES}

1 Source Term Concentrations for Scale and Sludge $\ldots \ldots \ldots \ldots \ldots \ldots \ldots \ldots \ldots$

2 Methodologies Used to Model NORM Management and Disposal Scenarios . . . . . . . 19

3 Summary of Doses Associated with Equipment Cleaning Facilities . . . . . . . . 27

4 Summary of Doses from Ingestion of Groundwater $\ldots \ldots \ldots \ldots \ldots \ldots \ldots \ldots$

5 Summary of Annual Doses for the Recycling Scenarios . . . . . . . . . . . . . 49 


\section{TABLES (Cont.)}

6 Summary of Annual Doses Associated with Radioactive Emissions

from a Steel Smelting Facility

7 Annual Public Individual Doses for Unrestricted Shallow Burial of NORM-Contaminated Scrap Metal

A.1 Assumptions and Input Parameters Used to Model the Pipe Cleaner Scenarios . . . . . 61

A.2 Assumptions and Input Parameters Used to Model the Storage

Vessel Cleaner Scenario

A.3 Assumptions and Input Parameters Used to Model the Storage Yard Scenarios

A.4 Assumptions and Input Parameters Used to Model the Subsurface Disposal Scenarios

A.5 Assumptions and Input Parameters Used to Model the Landspreading with Dilution Scenario

A.6 Input Parameters Used to Model the External Pathway for the Smelting Scenarios . . . 66

A.7 Input Parameters Used to Model the Internal Pathways for the Smelting Scenarios 


\section{ACKNOWLEDGMENTS}

Research for this report was sponsored by the U.S. Department of Energy, Office of Policy, and conducted under the direction of John Gasper, Argonne National Laboratory, Washington, D.C. The authors wish to acknowledge the assistance of Sammy Cooper, Campbell Wells Corp., Lafayette, Louisiana; Kevin Grice, Texaco Exploration and Production, Inc., Houston, Texas; Mel Hebert, Newpark Environmental Services, Bridge City, Texas; Mike Loudermilk, American Petroleum Institute, Dallas, Texas; Bill Russo, Office of Radiation and Indoor Air, U.S. Environmental Protection Agency, Washington, D.C.; and L. Max Scott, Louisiana State University, Baton Rouge, Louisiana, who provided valuable insights and information regarding existing conditions in the petroleum industry. In addition, the authors would like to thank Halil Avci, S.Y. Chen, Kou-John Hong, Bassel Nabelssi, Manjula Nimmagadda, John Quinn, and Dave Tomasko, Argonne National Laboratory, Argonne, Illinois, for their valuable input and critical reviews. 


\section{NOTATION}

The following is a list of acronyms, abbreviations, and initialisms (including units of measure) used in this document. Acronyms used in tables only are defined in the respective tables.

\section{ACRONYMS, ABBREVIATIONS, AND INITIALISMS}

$\begin{array}{ll}\text { ANL } & \text { Argonne National Laboratory } \\ \text { API } & \text { American Petroleum Institute } \\ \text { CFR } & \text { Code of Federal Regulations } \\ \text { CRCPD } & \text { Conference of Radiation Control Program Directors, Inc. } \\ \text { D } & \text { decay progeny } \\ \text { DOE } & \text { U.S. Department of Energy } \\ \text { EPA } & \text { U.S. Environmental Protection Agency } \\ \text { IAEA } & \text { International Atomic Energy Agency } \\ \text { ICRP } & \text { International Commission on Radiological Protection } \\ \text { LDEQ } & \text { Louisiana Department of Environmental Quality } \\ \text { NORM } & \text { naturally occurring radioactive materials } \\ \text { NRC } & \text { Nuclear Regulatory Commission }\end{array}$

\section{RADIONUCLIDES}

$\begin{array}{ll}\mathrm{Pb}-210 & \text { lead-210 } \\ \mathrm{Ra}-226 & \text { radium-226 } \\ \mathrm{Ra}-228 & \text { radium-228 } \\ \mathrm{Th}-232 & \text { thorium-232 } \\ \mathrm{U}-238 & \text { uranium-238 }\end{array}$

\section{UNITS OF MEASURE}

$\begin{array}{ll}\mathrm{bbl} & \text { barrel(s) } \\ \mathrm{Bq} & \text { becquerel } \\ \mathrm{Ci} & \text { curie(s) } \\ \mathrm{cm} & \text { centimeter(s) } \\ \mathrm{cm} / \mathrm{s} & \text { centimeter(s) per second } \\ \mathrm{g} / \mathrm{h} & \text { gram(s) per hour } \\ \mathrm{g} / \mathrm{cm}^{3} & \text { gram(s) per cubic centimeter } \\ \mathrm{g} / \mathrm{m}^{3} & \text { gram(s) per cubic meter }\end{array}$




$\begin{array}{ll}\mathrm{gal} / \mathrm{min} & \text { gallon(s) per minute } \\ \mathrm{kg} & \text { kilogram(s) } \\ \mathrm{km} & \text { kilometer(s) } \\ \mathrm{L} / \mathrm{s} & \text { liter(s) per second } \\ \mu \mathrm{R} / \mathrm{h} & \text { microroentgen per hour } \\ \mathrm{m} & \text { meter(s) } \\ \mathrm{m}^{2} & \text { square meter(s) } \\ \mathrm{m}^{2} / \mathrm{d} & \text { square meter(s) per day } \\ \mathrm{mrem} & \text { millirem(s) } \\ \mathrm{mrem} / \mathrm{yr} & \text { millirem(s) per year } \\ \mathrm{m} / \mathrm{s} & \text { meter(s) per second } \\ \mathrm{pCi} & \text { picocurie(s) } \\ \mathrm{pCi} / \mathrm{g} & \text { picocurie(s) per gram } \\ \mathrm{pCi} / \mathrm{L} & \text { picocurie(s) per liter } \\ \mathrm{R} & \text { roentgen } \\ \mathrm{rem} & \text { roentgen equivalent man } \\ \mathrm{rem} / \mathrm{yr} & \text { rem per year } \\ \mathrm{s} / \mathrm{L} & \text { second(s) per liter } \\ \mathrm{t} & \text { metric ton(s) } \\ & \end{array}$




\title{
RADIOLOGICAL DOSE ASSESSMENT RELATED TO MANAGEMENT OF NATURALLY OCCURRING RADIOACTIVE MATERIALS GENERATED BY THE PETROLEUM INDUSTRY
}

by

\author{
K.P. Smith, D.L. Blunt, G.P. Williams, and C.L. Tebes
}

\begin{abstract}
A preliminary radiological dose assessment of equipment decontamination, subsurface disposal, landspreading, equipment smelting, and equipment burial was conducted to address concerns regarding the presence of naturally occurring radioactive materials (NORM) in production waste streams. The assessment estimated maximum individual dose equivalents for workers and the general public. Sensitivity analyses of certain input parameters also were conducted. On the basis of this assessment, it is concluded that (1) regulations requiring workers to wear respiratory protection during equipment cleaning operations are likely to result in lower worker doses, (2) underground injection and downhole encapsulation of NORM wastes present a negligible risk to the general public, and (3) potential doses to workers and the general public related to smelting NORM-contaminated equipment can be controlled by limiting the contamination level of the initial feed. It is recommended that (1) NORM wastes be further characterized to improve studies of potential radiological doses; (2) states be encouraged to permit subsurface disposal of NORM more readily, provided further assessments support this study's results; (3) further assessment of landspreading NORM wastes be conducted; and (4) the political, economic, sociological, and nonradiological issues related to smelting NORM-contaminated equipment be studied to fully examine the feasibility of this disposal option.
\end{abstract}

\section{SUMMARY}

The presence of naturally occurring radioactive materials (NORM) in oil and gas production and processing wastes has been recognized since the 1930s. However, concerns about the possible associated health risks did not arise until the mid-1980s, when the industry and regulators realized that NORM occurrence was more widespread than originally thought and that activity levels could be quite high. Although it is widely acknowledged that both workers and the general public may be at risk of radiation exposure resulting from NORM-contaminated waste streams, the magnitude of 
that risk and the resultant need to regulate NORM have been debated. This dose assessment ${ }^{1}$ adds new information to the debate surrounding NORM regulation by (1) estimating doses related to a set of management and disposal methods that includes several currently acceptable methods, a prospective method, and two past practices; (2) comparing the estimated doses related to these different methods; and (3) conducting a sensitivity analysis of some of the key input parameters.

The scope of this dose assessment includes six NORM management and disposal activities, equipment decontamination, downhole encapsulation, underground injection, landspreading with dilution, equipment smelting, and unrestricted shallow burial of contaminated equipment. Disposal at licensed NORM or low-level radioactive waste disposal facilities was not included in this assessment on the assumption that the associated doses are acceptable by virtue of the licensed status of the facilities. Maximum individual dose equivalents associated with the selected activities were estimated for both workers and the general public and were used as the basis for comparison between disposal options, as appropriate. Collective doses were considered to be beyond the scope of this study and were not calculated. Sensitivity analyses of some of the key input parameters were conducted to assess their impact on the predicted doses.

Adequate characterization of the source term concentration has been a major limitation of most NORM risk assessments conducted to date. Available data indicate that the total radium concentrations in scale and sludge vary greatly, from undetectable levels to extremely high measurements; however, these data have not been aggregated into a comprehensive data set that would allow the calculation of statistically representative source term concentrations. The source term concentrations used in this assessment were based on the scale and sludge composite concentrations used in a risk assessment conducted by the U.S. Environmental Protection Agency and the State of Louisiana. The median concentration for scale was assumed to be 480 picocuries $^{2}$ per gram ( $\mathrm{pCi} / \mathrm{g}$ ) total radium and the 75 th-percentile concentration for scale was assumed to be $2,700 \mathrm{pCi} / \mathrm{g}$ total radium. For sludge, the median concentration was assumed to be $75 \mathrm{pCi} / \mathrm{g}$ total radium.

\section{CONCLUSIONS}

Better characterization of the source term is needed to adequately assess the radiological impacts associated with various NORM management and disposal alternatives. The results from this assessment must be regarded as preliminary. Absolute health risks cannot be determined from these preliminary estimates because of the uncertainty related to the source term concentrations and

1 This assessment was conducted by utilizing data available through January 1995 and does not incorporate more recently published data or studies. Similarly, it discusses the regulatory setting as it existed in January 1995.

${ }^{2}$ A curie is a unit of radioactivity corresponding to $3.7 \times 10^{10}$ disintegrations per second. A picocurie is equal to one trillionth of a curie. 
because of the conservative nature of many of the input assumptions. For the same reasons, conclusions about risk to human health should not be drawn by comparing the estimated doses with existing or proposed regulatory standards.

Given these limitations, it is still possible to draw some general conclusions regarding the selected NORM management and disposal methods and to compare the estimated doses as a preliminary indication of the relative risks associated with each method. The existing regulated standards can be used to provide a benchmark value that adds perspective to the results. The following conclusions can be drawn on the basis of the results of this assessment:

- External exposures are roughly equivalent for workers at licensed and at unregulated equipment cleaning facilities. However, the potential doses to workers from inhalation or ingestion of NORM particulates may be greater for workers at unregulated facilities if respirators and protective clothing are not used during dry pipe-cleaning operations. Additional information about the dry pipe-cleaning processes (e.g., dust loading factors, worker practices) and the source term are needed to fully quantify the potential doses related to the inhalation and ingestion pathways.

- The estimated doses to the general public associated with casing failures during underground injection of NORM-contaminated wastes are higher than those associated with casing failures during downhole encapsulation. However, the estimated doses associated with either subsurface disposal method appear to be so low that risk to the general public from either method is negligible.

- Assuming conservative residential land-use (i.e., individuals living and growing their own food on-site), landspreading with dilution presents the highest potential dose to the general public of all of the methods assessed in this study.

- Estimated doses to the general public from both smelter stack emissions and use of products made from recycled steel and slag are lower by at least two orders of magnitude than estimated doses related to unrestricted shallow burial of the same quantity of NORM-contaminated equipment. Furthermore, doses resulting from smelting contaminated equipment can be controlled by limiting the contamination level of the initial feed. 


\section{RECOMMENDATIONS}

On the basis of these conclusions, the following studies and potential policy actions are recommended:

- NORM wastes generated by the petroleum industry should be characterized further to improve efforts to assess potential doses to workers and the general public. Further characterization of the source term concentration is particularly important. Existing data collected at the state and company levels should be aggregated to improve efforts to calculate statistically representative source term concentrations.

- Provided further assessment supports the results of this study indicating that subsurface disposal methods constitute realistically safe methods for disposing of NORM-contaminated wastes, state regulatory agencies should be encouraged to permit subsurface disposal projects more readily. Underground injection projects should not be considered to pose a significantly greater risk to the general public than downhole encapsulation projects. Regulators should strive to educate the public about the realistic risks related to subsurface disposal so that unfounded fears do not complicate the permitting process.

- Further assessment of the potential radiological doses to the general public resulting from landspreading with dilution is needed to fully evaluate this disposal alternative.

- Because this study did not consider the political, economic, sociological, and nonradiological issues related to smelting NORM-contaminated equipment generated by the petroleum industry, further study is needed to fully examine the feasibility of this disposal option. 


\section{INTRODUCTION}

\subsection{BACKGROUND}

Oil and gas extraction and processing operations sometimes accumulate naturally occurring radioactive materials (NORM) at elevated concentrations in by-product waste streams. The sources of most of the radioactivity are isotopes of uranium-238 (U-238) and thorium-232 (Th-232) naturally present in subsurface formations from which oil and gas are produced. The primary radionuclides of concern in NORM wastes are radium-226 (Ra-226), of the U-238 decay series, and radium-228 (Ra-228), of the Th-232 decay series. Other radionuclides of concern include those that form from the decay of Ra-226 and Ra-228; these decay progeny are shown in Figures 1 and 2, which depict the decay chains for U-238 and Th-232, respectively.

The production waste streams most likely to be contaminated by elevated radium concentrations include produced water, scale, and sludge. Radium, which is slightly soluble, can be mobilized in the liquid phases of a formation and transported to the surface in the produced water stream. Dissolved radium either remains in solution in the produced water or, if the conditions are right, precipitates out in scales or sludges. Production and processing equipment may contain residual quantities of NORM-contaminated water, scale, or sludge that can cause disposal and exposure problems when the equipment is taken off-line for maintenance, repair, or replacement. Natural gas production and processing equipment also may be contaminated with a thin film of lead-210 $(\mathrm{Pb}-210)$ plated onto interior surfaces.

Although the presence of NORM in petroleum industry wastes has been recognized since the 1930s, concerns about possible associated health risks did not arise until the mid-1980s, when industry and regulators realized that NORM occurrence was more widespread than originally thought and that activity levels could be quite high. Although it is widely acknowledged that both workers and the general public may be at risk of radiation exposure resulting from NORMcontaminated waste streams, the magnitude of that risk and the resultant need to regulate NORM have been debated. This dose assessment adds new information to the debate surrounding NORM regulation by (1) estimating doses related to a set of management and disposal methods that includes several currently acceptable methods, a prospective method, and two past practices; (2) comparing the estimated doses related to these different methods; and (3) conducting a sensitivity analysis of some of the key input parameters.

\subsection{REGULATORY SETTING}

Currently, no federal regulations specifically address handling and disposal of NORM waste. There has been speculation that NORM regulation could be addressed under the Clean Water 


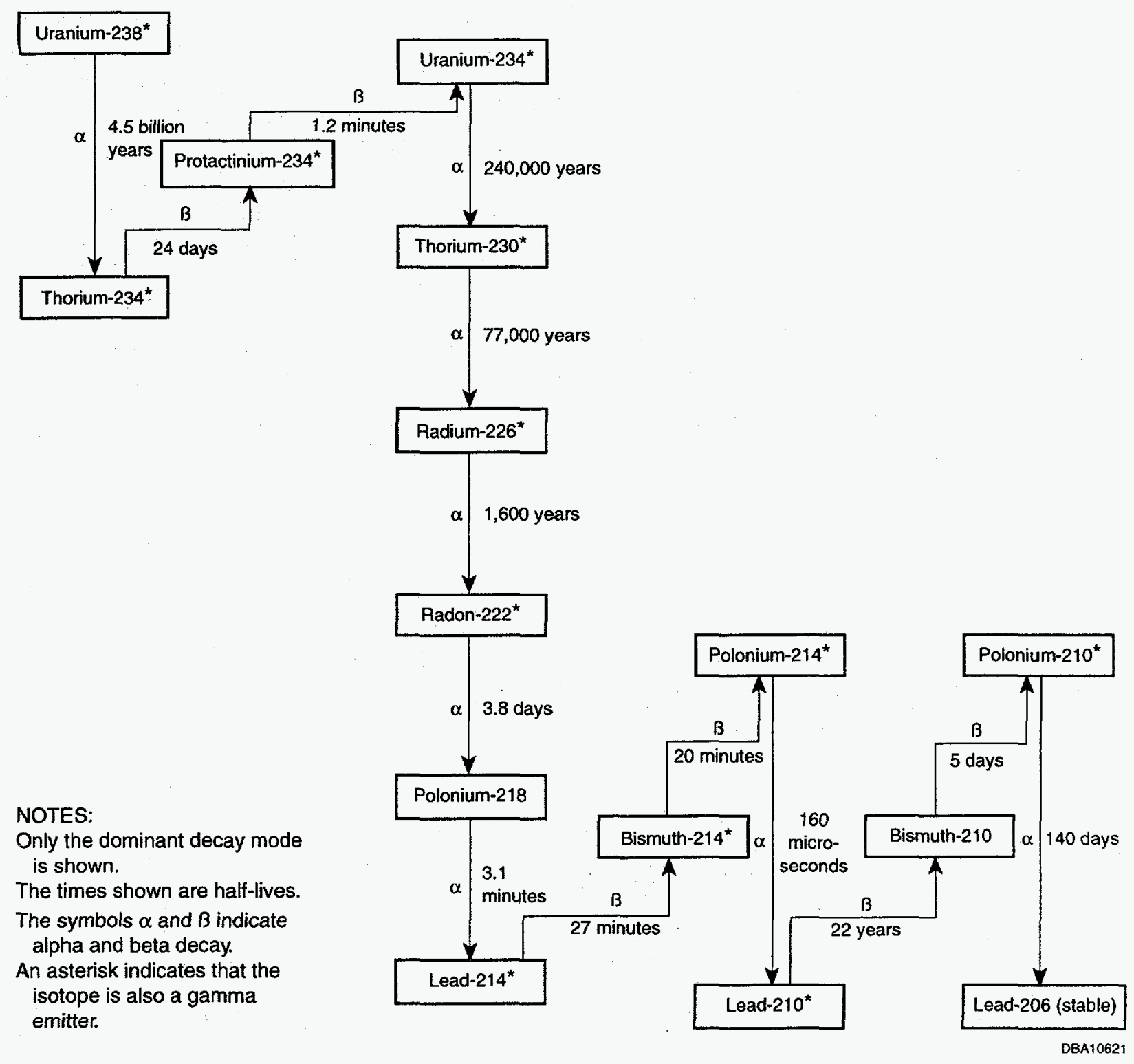

FIGURE 1 Uranium-238 Decay Series

Act, the Safe Drinking Water Act Underground Injection Control program, and the Toxic Substances Control Act; however, the U.S. Environmental Protection Agency (EPA) has taken no action along these lines to date. In the absence of federal regulations, individual states have taken responsibility for developing their own regulatory programs. These programs have been evolving rapidly over the last few years. Several states have promulgated NORM regulations, and many others are reviewing NORM issues and the need for specific regulations. In addition, the Conference of Radiation Control Program Directors, Inc. (CRCPD), ${ }^{3}$ has drafted recommended NORM regulations, referred to as the Part N regulations, for use by states in developing their NORM regulatory programs (CRCPD 1994).

${ }^{3}$ The CRCPD is made up primarily of officials from state radiation control agencies. 


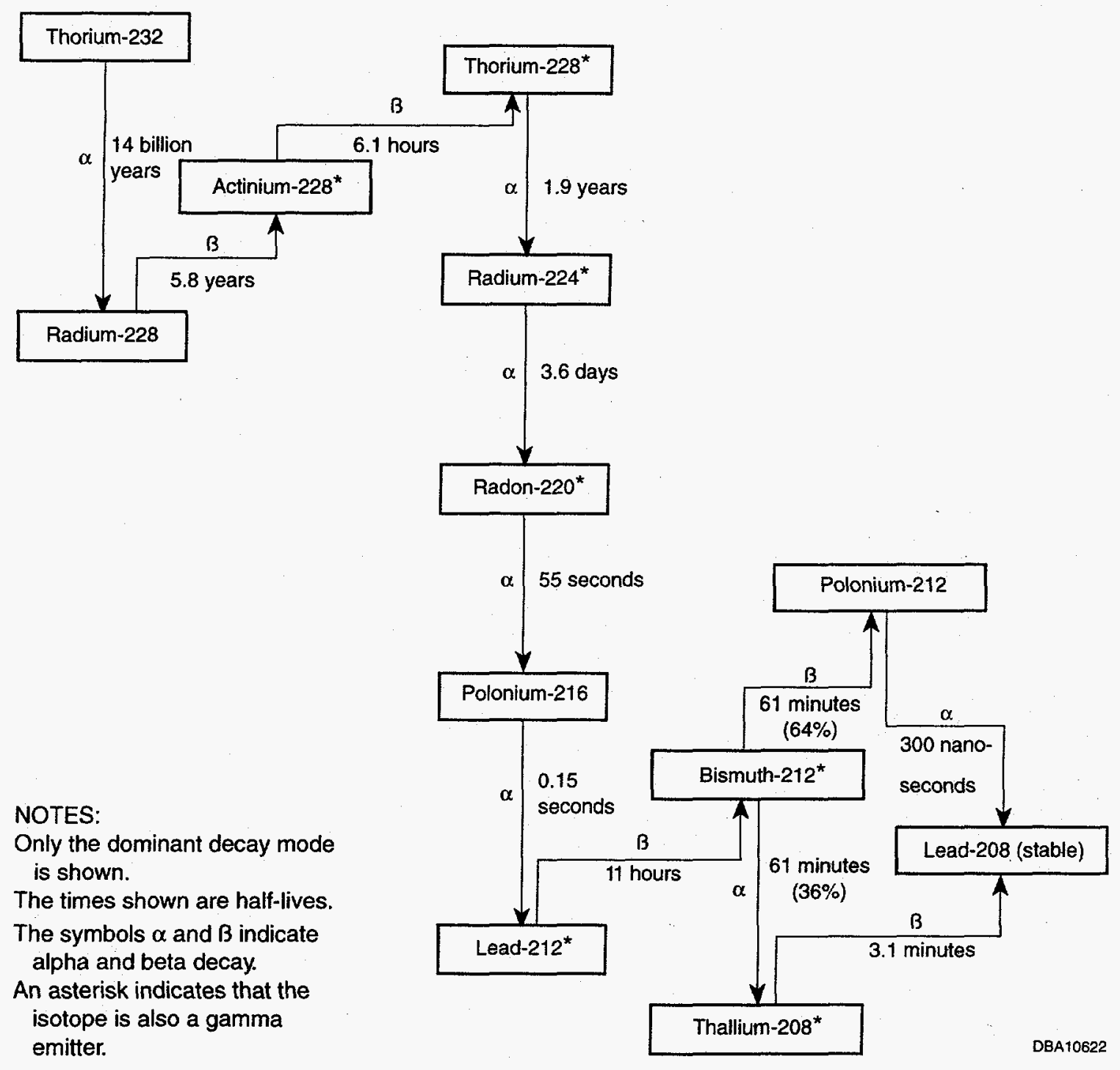

\section{FIGURE 2 Thorium-232 Decay Series}

The existing state regulatory programs establish standards for (1) the licensure of parties possessing, handling, or disposing of NORM; (2) the release of NORM-contaminated equipment and land; (3) worker protection; and (4) NORM disposal. In general, the effect of state-level NORM regulation has been to limit the number of disposal options available to the petroleum industry. In states that have enacted NORM regulations, some of the previously acceptable waste disposal methods (e.g., shallow burial) are no longer allowed when the waste stream is known to contain NORM in excess of a specified activity concentration level. Similarly, methods for cleaning contaminated equipment have been modified to reduce potential occupational exposures. The reuse or recycling of contaminated equipment also has been restricted to reduce the potential for public exposures. 
Under existing regulations for workers classified as radiation workers by state or federal law, doses are required to be as low as reasonably achievable, not to exceed an annual dose ${ }^{4}$ of $5 \mathrm{rem} / \mathrm{yr}$, as specified in Title 10, Code of Federal Regulations (CFR), Part 20. This limit applies to those workers who handle NORM if they are classified as radiation workers by state regulations; otherwise, NORM workers are subject to dose limits that apply to the general public. The currently accepted public dose limit ${ }^{5}$ is 100 millirem per year (mrem/yr) from all sources (ICRP 1991). However, the CRCPD has proposed a public dose limit of $25 \mathrm{mrem} / \mathrm{yr}$ from a single NORM source (CRCPD 1994), and the EPA has proposed a public dose limit of $15 \mathrm{mrem} / \mathrm{yr}$ from any single source. ${ }^{6}$ The current maximum concentration level for Ra-226 and Ra-228 combined in drinking water is $5 \mathrm{pCi} / \mathrm{L}$, as specified in $40 \mathrm{CFR} 141$; the EPA has proposed a maximum level for either $\mathrm{Ra}-226$ or $\mathrm{Ra}-228$ of $20 \mathrm{pCi} / \mathrm{L}$ (EPA 1994).

At the present time, regulatory limits on the release of radioactively contaminated metals have not been established. The International Atomic Energy Agency (IAEA) is in the process of deriving recommended limits that could apply to the release of contaminated metal generated by either the nuclear energy industry or the U.S. Department of Energy (DOE) (IAEA 1994). The IAEA is proposing a clearance level ${ }^{7}$ (i.e., unrestricted release criterion) of 0.3 becquerel per gram (i.e., 8 picocuries per gram $[\mathrm{pCi} / \mathrm{g}])^{8}$ for $\mathrm{Ra}-226, \mathrm{Ra}-228$, $\mathrm{Th}-228$, and $\mathrm{Pb}-210$; metals contaminated with higher activity levels could not be released from the generator to a commercial smelter or other facility. The IAEA has no regulatory authority. over the petroleum industry, and the petroleum industry would not be subject to this limit if adopted; however, this type of limit could set a precedent for the scrap metal industry to follow in adopting voluntary standards applicable to any contaminated metal, regardless of its source.

\subsection{SCOPE AND OBJECTIVES}

The scope of this dose assessment includes six NORM management and disposal activities: equipment decontamination, downhole encapsulation, underground injection, landspreading with dilution, equipment smelting, and unrestricted shallow burial of contaminated equipment. Equipment

${ }^{4}$ Rem stands for roentgen equivalent man. It is a unit of radiation dose that incorporates both the amount of ionizing radiation absorbed by tissue and the relative ability of that radiation to produce particular biological change. The unit is frequently applied to total body exposure for all types of ionizing radiation.

5 A millirem is equal to one thousandth of a rem.

6 Contained in the EPA's "Draft Proposed Rule, EPA Radiation Site Cleanup Regulation," proposed to be located in Title 40, Code of Federal Regulations, Part 196, when promulgated.

${ }^{7}$ Becquerel (Bq) is the Système International (SI) unit of radioactivity, signifying one nuclear disintegration per second.

${ }^{8}$ A curie is a unit of radioactivity corresponding to $3.7 \times 10^{10}$ disintegrations per second. A picocurie is equal to one trillionth of a curie. 
decontamination was chosen in part because no previous assessments of this activity have been published, and also because it provides an opportunity to compare worker exposures at licensed and unlicensed equipment cleaning facilities. The two subsurface disposal methods, underground injection and downhole encapsulation, were chosen because both methods are regarded by the industry as acceptable methods, but regulatory agencies have been willing to approve only downhole disposal; modeling both of these methods allows a comparison of their related doses. The disposal of NORM-contaminated wastes by landspreading was modeled to compare estimated potential doses related to varying degrees of dilution. Landspreading of NORM waste is no longer allowed by some state regulatory programs; it is allowed with restrictions (e.g., dilution must be to background plus $5 \mathrm{pCi} / \mathrm{g}$ or less) by other state programs but is unregulated in most states that do not have any specific NORM regulations. The smelting scenario was included because it may present a viable option that has not been fully developed. Disposal at licensed NORM or low-level radioactive waste disposal facilities was not included in this assessment on the assumption that the associated doses are acceptable by virtue of the licensed status of the facilities.

Maximum individual dose equivalents associated with the selected activities were estimated and used as the basis for comparison between disposal options, as appropriate. Collective doses were considered to be beyond the scope of this study and were not calculated. Limited sensitivity analyses were conducted for key input parameters for which definitive data are not available. In some cases (e.g., groundwater gradient, hydraulic conductivities), definitive data are not available because the range of possible conditions is so great. In other cases (e.g, source term concentration, $\mathrm{Ra}-226: \mathrm{Ra}-228$ ratio), definitive data are not available because further waste characterization is needed.

The primary objectives of this study were to conduct the following:

- An estimation of the potential doses to workers and the general public associated with the NORM management and disposal activities noted above,

- A comparison of the relative dose of some of these activities, and

- A sensitivity analysis of certain input parameters. 


\section{CHARACTERIZATION OF NORM WASTES}

\subsection{SOURCE TERM CHARACTERIZATION}

Numerous surveys have been conducted by industry and state agencies to characterize the occurrence and distribution of NORM. Unfortunately, most of the data from these surveys are not readily available, primarily because they have been collected by private companies and are considered proprietary. The lack of access to this proprietary data, coupled with the fact that the available data have not been aggregated to a national level, makes it difficult to fully characterize NORM wastes, particularly with respect to calculating average NORM activity levels. Data published from some of the earlier surveys (Baird et al. 1990; Otto 1989; Snavely 1989) indicate that total radium concentrations typically range from undetectable levels to several thousand picocuries per liter or gram. However, anomalously high concentrations up to $410,000 \mathrm{pCi} / \mathrm{g}$ in scale (EPA 1993a), 700,000 pCi/g in sludge (Fisher and Hammond 1994), and 29,000 pCi/L in water (Minnaar 1994) have been reported in more recent studies, indicating that the possible range of radium concentrations is greater than originally thought. These very high concentrations probably represent outliers at the upper limits of possible radium concentrations. However, because data unavailability prevents a clear description of the distribution of radium concentrations in NORM, this conclusion cannot be confirmed. Because of these issues, it is not possible to calculate a statistically representative average source term concentration.

The most comprehensive study conducted to date, sponsored by the American Petroleum Institute (API), measured external gamma exposures from contaminated equipment and converted those readings to total radium concentrations on the basis of several assumptions (Otto 1989). The data from that survey cannot be used to derive statistically representative source term concentrations because (1) the survey did not provide adequate coverage of some geographic areas, (2) it was limited to those companies that responded, (3) statistically designed sampling schemes were not used, and (4) the conversion from external gamma readings to radium concentrations is heavily dependent on several highly variable factors (e.g., equipment geometry, shielding factors, internal distribution of radium). In addition, the survey is considered to be biased toward high concentrations because measurements were collected only from equipment expected to contain NORM on the basis of the field's tendency to produce scale or large volumes of water (Otto 1989). The API, Gas Research Institute, and DOE are sponsoring a study to further characterize NORM concentrations in petroleum wastes; however, that project is still underway, and no results are available.

Despite their limitations, the API survey data have been used in NORM risk assessments (EPA 1993a,b) to calculate a median source term concentration because they are the most comprehensive data available. They were used in this assessment for the same reason; however, this assessment attempted to place boundaries on the uncertainty related to the source term 
concentrations by calculating doses with both a median and a 75th-percentile composite concentration for many of the scenarios.

Available data are adequate to determine that, in general, NORM concentrations are greatest in the scales and sludges that form in water-handling equipment and that activity levels decrease with distance from the wellhead. Total radium concentrations are dependent on the amount of radium present in the subsurface formation, formation water chemistry, extraction processes, treatment processes, and age of production. In general, radium solubility increases in water that has (1) a high saline content and (2) either low or high $\mathrm{pH}$ values. Radium precipitation rates increase with decreasing temperature and pressure conditions, such as those encountered when subsurface fluids are brought to the surface. Extraction processes (e.g., waterfloods, steam floods, chemical floods) and treatment processes that alter formation water chemistry or effect temperature or pressure changes may increase or decrease radium mobility. Most radium is brought to the surface in solution in the water produced along with the hydrocarbons (produced water). As a result, a higher water production rate, such as is characteristic of older fields, can result in increased NORM concentrations.

The source term concentrations used in this assessment were based on the scale and sludge composite concentrations used in a risk assessment conducted by the EPA and the state of Louisiana (EPA 1993b). In that study, median, 75th-percentile, and maximum concentrations in scale and sludge were derived from more than 3,000 external gamma measurements collected in Louisiana as part of the API survey. The median and 75th-percentile concentrations calculated for the Louisiana data, provided in Table 1, were used for this assessment because they represent the most complete set of data available; the median concentrations also were used by the EPA in its diffuse NORM waste study (EPA 1993a). On the basis of the Louisiana data, the median concentration for scale is $480 \mathrm{pCi} / \mathrm{g}$ total radium and the 75 th-percentile concentration for scale is $2,700 \mathrm{pCi} / \mathrm{g}$ total radium. For sludge, the median concentration is $75 \mathrm{pCi} / \mathrm{g}$ total radium. Because doses related to the 75th-percentile concentrations in sludge were not calculated in this assessment, only the median concentrations in sludge are provided in Table 1.

Although definitive data describing the concentration ratio of $\mathrm{Ra}-226$ to $\mathrm{Ra}-228$ are not available, a ratio of $3: 1$ was assumed. In addition, to be conservative, secular equilibrium ${ }^{9}$ was assumed for the radium decay progeny. Dose calculations were performed for the principal radionuclides in the decay series. The term principal refers to those radionuclides in the decay series with half-lives of more than one year. The principal radionuclides listed in Table 1 are Ra-226,

\footnotetext{
${ }^{9}$ Secular equilibrium refers to the stable relationship established in nature between a radioactive element that has a long half-life and a decay product that has a much shorter half-life. For example, Ra- 226 has a half-life of about 1,600 years. As this element decays and emits radiation, $\mathrm{Rn}-222$, which has a half-life of about 3.8 days, is produced. Over time (after seven daughter half-lives), an equilibrium is established between the concentrations of these two elements such that the activity of each element is equal.
} 
TABLE 1 Source Term Concentrations for Scale and Sludge

\begin{tabular}{lccc}
\hline & \multicolumn{3}{c}{ Concentration $(\mathrm{pCi} / \mathrm{g})$} \\
\cline { 2 - 4 } Radionuclide & Median Scale & 75th-Percentile Scale & Median Sludge \\
\hline & & & \\
Radium-226 & 360 & 2,025 & 56 \\
Lead-210 & 360 & 2,025 & 56 \\
Radium-228 & 120 & 675 & 19 \\
Thorium-228 & 120 & 675 & 19 \\
Total radium & 480 & 2,700 & 75 \\
\hline
\end{tabular}

Source: EPA (1993b).

$\mathrm{Pb}-210, \mathrm{Ra}-228$, and $\mathrm{Th}-228$. The chain of decay products of a principal radionuclide (i.e., the associated radionuclides) extending to (but not including) the next principal radionuclide were assumed to be in secular equilibrium with the principal radionuclide. The contribution from these associated radionuclides were included with the principal radionuclide in the dose calculations. These assumptions regarding source term characterization are consistent with assumptions used in several previous studies (Baird et al. 1990; EPA 1993a,b).

\subsection{PRODUCED WATER}

Available data indicate that total radium concentrations range from undetectable levels to $2,800 \mathrm{pCi} / \mathrm{L}$ in most produced waters (Snavely 1989), although extreme values as high as $29,000 \mathrm{pCi} / \mathrm{L}$ have been measured (Minnaar 1994). The amount of radium present in produced water depends on the amount of radionuclides present in the subsurface formation and on formation fluid chemistry. Radium concentrations tend to be higher in more saline waters, although high salinity does not always indicate the presence of radium.

Soluble radium may precipitate or remain in solution, depending on water salinity and on temperature and pressure phase changes. If conditions are conducive to precipitation (decreasing temperature and pressure), radium usually coprecipitates with other alkaline earth elements in scales and sludges that form inside production or processing equipment. 


\subsection{SCALE}

NORM contamination of scale can occur when dissolved radium in produced water coprecipitates with barium, strontium, or calcium sulfates. These sulfates form hard, insoluble deposits on the inside of piping, filters, brine disposal/injection wells, and other water handling equipment. Over time, scale deposits thicken and may need to be removed to ensure that equipment continues to operate properly. The EPA estimates that approximately 25,000 metric tons (t) of NORM-contaminated scale is generated annually by the petroleum industry (EPA 1993a).

Total radium concentrations in scale typically range from undetectable levels to several thousand picocuries per gram (Baird et al. 1990); however, concentrations as high as 410,000 pCi/g have been reported (EPA 1993a). The median concentration for total radium in scale used in this study was $480 \mathrm{pCi} / \mathrm{g}$ (360 pCi/g Ra-226 and $120 \mathrm{pCi} / \mathrm{g} \mathrm{Ra}-228$ ). The 75th-percentile concentration for total radium was $2,700 \mathrm{pCi} / \mathrm{g}(2,025 \mathrm{pCi} / \mathrm{g} \mathrm{Ra}-226$ and $675 \mathrm{pCi} / \mathrm{g} \mathrm{Ra}-228)$. The density of scale is approximately $2.6 \mathrm{~g} / \mathrm{cm}^{3}$ (EPA 1993a). Radon emanation from scale has not been well-characterized, but because the precipitated scale is very dense, the amount of radon emanating from the pore spaces is low. A radon emanation coefficient ${ }^{10}$ of 0.05 generally is assumed for scale (Baird et al. 1990; EPA 1993a).

\subsection{SLUDGE}

Sludge deposits consist of accumulations of heavy hydrocarbons, tight emulsions, produced formation sand, and minor amounts of corrosion and scaly debris that settle out of suspension in some oil field equipment. NORM accumulates in sludge when radium coprecipitates with silicates and carbonates inside piping, separators, heater/treaters, storage tanks, and any other equipment where produced water is handled. The EPA estimates that approximately $225,000 \mathrm{t}$ of NORMcontaminated sludge is generated annually (EPA 1993a).

Typically, NORM concentrations range from undetectable levels to $300 \mathrm{pCi} / \mathrm{g}$ (Baird et al. 1990 ), although sludge samples measuring as high as $700,000 \mathrm{pCi} / \mathrm{g} \mathrm{Ra}-226$ have been documented (Fisher and Hammond 1994). The median concentration for total radium in sludge used in this study was $75 \mathrm{pCi} / \mathrm{g}$ ( $56 \mathrm{pCi} / \mathrm{g} \mathrm{Ra}-226$ and $19 \mathrm{pCi} / \mathrm{g}$ Ra-228). A 75th-percentile value was not used in this assessment because all scenarios except one (the vessel cleaner at an equipment cleaning facility) were based on scale concentrations only. The density of sludge is approximately $1.6 \mathrm{~g} / \mathrm{cm}^{3}$ (Baird et al. 1990; EPA 1993a). The amount of radon emanating from sludge is higher than that for scale, primarily because of the more granular nature of sludge. The typical radon emanation coefficient for sludge used in other studies is 0.2 (Baird et al. 1990; EPA 1993a).

\footnotetext{
${ }^{10}$ The emanation coefficient factor is the fraction of radon atoms that escape the grain material containing the parent nuclide into the gaseous, porous space between the grains.
} 


\subsection{CONTAMINATED EQUIPMENT}

NORM-contaminated sludge and scale accumulate inside production and processing equipment. NORM contamination tends to be greatest in equipment where produced water is handled or stored, such as water lines, flow lines, injection wellheads, vapor recovery units, water storage tanks, heater/treaters, and separators. When the contaminated equipment is taken off-line, the NORM present inside can cause disposal problems. Some types of equipment (e.g., piping, storage tanks) can be cleaned to remove the contaminated sludge and scale. Cleaned equipment may be reused if it is in good condition; however, the cleaning process generates radioactive wastes that require disposal. Other types of equipment (e.g., wellhead filters, pumps, screens) cannot be cleaned easily and must be disposed of intact.

Natural gas production and processing equipment may be contaminated with a thin film of $\mathrm{Pb}-210$ plated onto interior surfaces. Lead-210 sometimes is produced along with natural gas, partitioned mainly between the propane and ethane fractions. Lead- 210 contamination primarily poses a potential health threat only when the equipment is opened to expose the interior surfaces. Because of the need for substantial data gathering, this form of NORM contamination was not addressed in this study.

The median exposure levels for oil production equipment range from 2 to 42 microroentgen per hour $(\mu \mathrm{R} / \mathrm{h})$ above background; ${ }^{11}$ median exposure levels for gas processing equipment range from 2 to $76 \mu \mathrm{R} / \mathrm{h}$ above background (median background level $=7 \mu \mathrm{R} / \mathrm{h}$ ) (Otto 1989). Extreme values as high as $5,300 \mu \mathrm{R} / \mathrm{h}$ have been measured in surveys conducted in Michigan (Minnaar 1994). It is difficult to predict the activity level of the NORM contained inside equipment from external measurements due to such variables as equipment geometry, shielding factors, scale or sludge thickness and age, and the distribution of NORM inside the equipment (API 1992).

Data describing the annual inventory of NORM-contaminated equipment generated by the petroleum industry are not available. An estimate of the annual inventory can be calculated by conservatively estimating the quantity of equipment generated annually through well abandonment and assuming that $10 \%$ of that quantity is contaminated with NORM. According to the API, the number of stripper wells abandoned annually between 1982 and 1992 ranged from a low of 9,000 wells to a high of 19,000 wells (Loudermilk 1994). To include both stripper and nonstripper wells, it is assumed that 18,000 wells are abandoned annually. Assuming a conservative average depth of $3,050 \mathrm{~m}$ per well, it is estimated that each abandoned well generated $96 \mathrm{t}$ of tubulars. The quantity of tubulars generated each year by well abandonments (18,000 wells times $96 \mathrm{t}$ per well) totals $1.728 \times 10^{6} \mathrm{t}$. Because the majority of equipment likely to be disposed of probably consists

${ }^{11}$ A roentgen is the quantity of radiation (either x-rays or gamma rays) that produces one electrostatic unit charge (e.g., $2.08 \times 10^{9}$ ion pairs) in $1 \mathrm{~cm}^{3}$ of dry air at $0^{\circ} \mathrm{C}$ and one atmosphere of pressure. A microroentgen is one millionth of a roentgen. 
of tubulars and small items (e.g., filters, valves) that cannot be cleaned easily and the calculation is based on conservative assumptions, the estimated annual quantity of tubulars is considered to approximate the annual quantity of equipment available for disposal. Assuming that $10 \%$ of that quantity is contaminated with NORM, the annual quantity of NORM-contaminated equipment available for disposal is estimated at $172,800 \mathrm{t}$. Ten percent is a reasonable estimate for NORM contamination given that the range observed by API is 7-15\% (Loudermilk 1994) and that the entire depth of a well is unlikely to be contaminated with NORM. 


\section{NORM MANAGEMENT AND DISPOSAL OPTIONS}

\subsection{PAST PRACTICES}

Before the hazards of NORM contamination were fully recognized, specific NORM management and disposal guidelines did not exist. The methods used to dispose of most NORMcontaminated wastes were determined primarily on the basis of other waste stream constituents. In many instances, there probably were no controls in place to contain the radioactivity of the wastes after disposal. Similarly, the handling and storage of NORM-contaminated wastes and equipment did not incorporate radiation worker protection standards, so no controls were in place to limit the potential for occupational exposures.

Traditionally, cleaning production and processing equipment has entailed a variety of mechanical processes (e.g., scraping, reaming, rattling) that may have placed workers at risk of radiation exposure. The removal of pipe scale usually was performed as a dry process without the use of respirators or masks to prevent ingestion or inhalation of particulates. If skin and eye protection were not used, workers could have come in contact with the scale and sludge. Monitoring was not conducted to determine if equipment contained NORM, what the activity levels were, or whether residual radioactivity was present after cleaning.

In the past, some NORM-contaminated scales and sludges recovered during equipment cleaning were disposed of via landspreading and shallow burial at such uncontrolled facilities as solid waste landfills. An assessment of NORM disposal options (Baird et al. 1990) concluded that these disposal methods provide only limited levels of isolation of the radioactivity. According to Baird et al.'s assessment (1990), the environmental pathway of greatest concern associated with landspreading is external irradiation; with uncontrolled burial, it is radon inhalation.

The reuse or recycling of oil field equipment generally was not controlled to prevent the release of NORM-contaminated equipment. In recent years, contaminated piping has been identified in fencing, cattle guards, buildings, and playgrounds. NORM-contaminated equipment also has been recycled via smelting, although the installation of detectors to identify radioactive items in incoming loads of scrap metal has limited this activity. The release of NORM-contaminated equipment potentially may have resulted in both occupational and general public exposures to radiation.

\subsection{ALTERNATIVE PRACTICES}

A number of factors have caused the petroleum industry to adopt methods for managing and disposing of NORM-contaminated wastes that are more restrictive and likely to provide greater 
isolation of the radioactivity than past practices. These factors include (1) increased awareness of NORM as a potential environmental concern, (2) increased state-level regulatory controls, and (3) the general public's concerns regarding the management of radioactive substances. Currently acceptable methods for management and disposal of NORM include

- Burial at either a licensed NORM or low-level radioactive waste disposal facility (approved by all state regulatory programs; applicable for scale, sludge, and small equipment);

- Dilution and storage at a licensed facility (approved by the State of Louisiana; applicable for scale and sludge);

- Downhole disposal via encapsulation inside the casing of a plugged and abandoned well (approved by several states; applicable for scale, sludge, water, and small equipment);

- Underground injection into subsurface formations (approved in only a few instances onshore to date; approved more readily offshore by the Minerals Management Service; applicable for scale, sludge, and water); and

- Regulated equipment decontamination and reuse within the industry (approved by all state regulatory programs to specified activity levels; process generates loose NORM-contaminated wastes that must be disposed of by other methods).

Another method of disposal of NORM, smelting contaminated equipment, also has been considered by the petroleum industry as a potentially viable option. However, the willingness of the scrap metal recycling industry to handle radioactive scrap metal needs further investigation. A limited (i.e., 26 responses) survey of steel companies conducted by the Petroleum Environmental Research Forum indicated that over $50 \%$ of the respondents were undecided regarding acceptance of NORM-contaminated equipment; only one respondent (4\%) expressed a willingness to recycle these items (Dehmel et al. 1992).

Figure 3 illustrates the disposal alternatives available or potentially available for handling NORM-contaminated wastes. Contaminated equipment can be disposed of via landfilling, smelting, or downhole disposal (for items such as tubulars, filters, valves, and screens that are small enough to fit inside the casing of another well). Alternatively, equipment can be decontaminated and subsequently reused or disposed of as a nonradioactive waste. Equipment smelting and decontamination both generate NORM-contaminated waste streams. Contaminated slag generated by smelting currently is not regulated; it may possibly be reused in a variety of commercial products, 


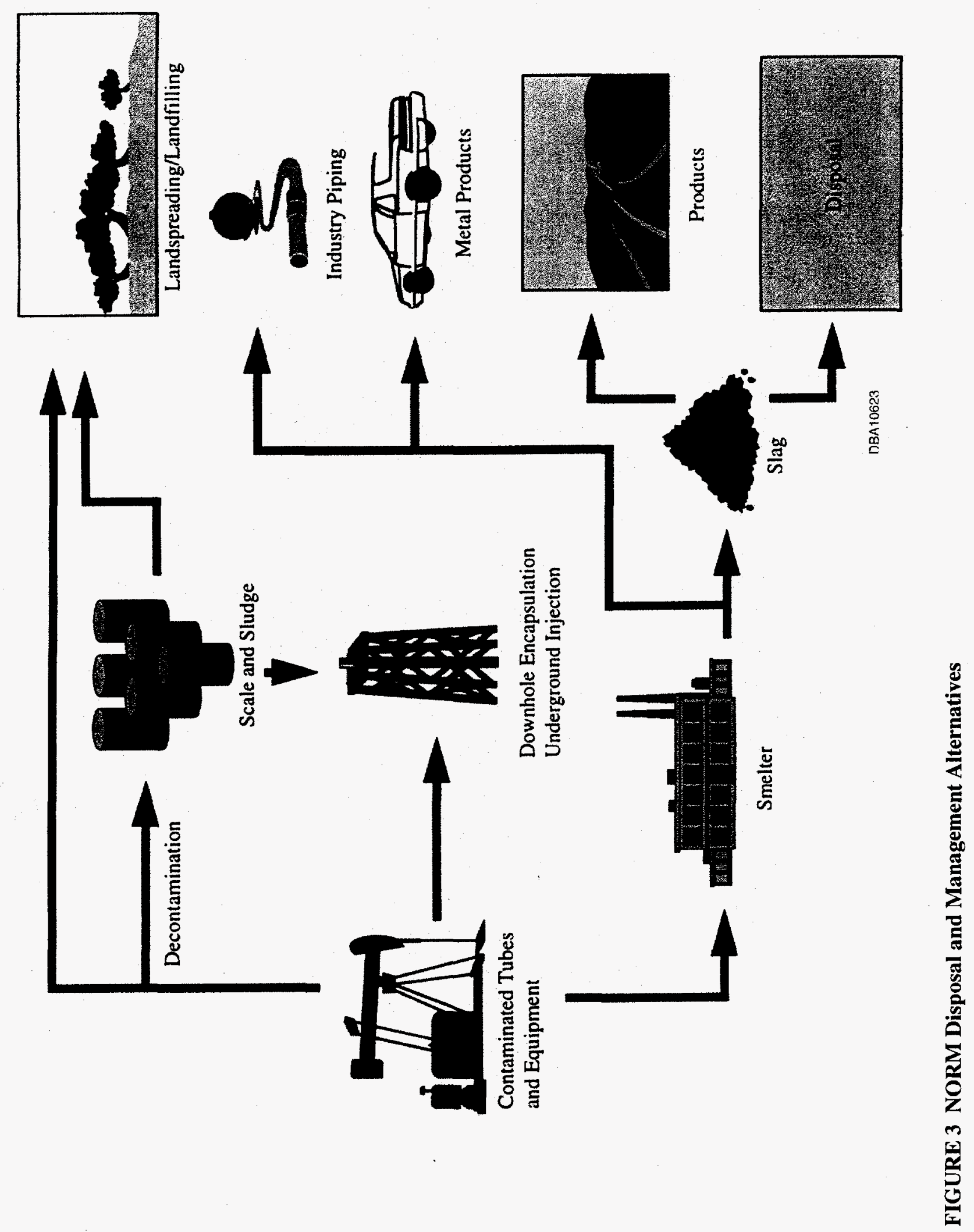


such as construction material, or it may need to be disposed of as a NORM-contaminated waste. Equipment decontamination generates NORM-contaminated scales and sludges that may be disposed of via landfilling, downhole encapsulation, underground injection, or landspreading.

Table 2 summarizes the exposure pathways of concern for each of the management and disposal methods included in this study and identifies the computer model used to estimate potential estimated doses.

TABLE 2 Methodologies Used to Model NORM Management and Disposal Scenarios

\begin{tabular}{|c|c|c|}
\hline $\begin{array}{l}\text { Management or } \\
\text { Disposal Method }\end{array}$ & Exposure Pathway & Model \\
\hline Equipment decontamination & $\begin{array}{l}\text { External irradiation } \\
\text { Inhalation/ingestion } \\
\text { Radon inhalation }\end{array}$ & $\begin{array}{l}\text { Microshield Version } 4^{\mathrm{a}} \\
\text { RESRAD-BUILD }^{\mathrm{b}} \\
\text { RESRAD }^{c}\end{array}$ \\
\hline Subsurface disposal & Groundwater ingestion & SWIFT II ${ }^{d}$ \\
\hline Landspreading with dilution & $\begin{array}{l}\text { External irradiation } \\
\text { Inhalation } \\
\text { Ingestion }\end{array}$ & $\begin{array}{l}\text { RESRAD } \\
\text { RESRAD } \\
\text { RESRAD }\end{array}$ \\
\hline Smelting equipment & $\begin{array}{l}\text { External irradiation } \\
\text { Inhalation/ingestion of particulates } \\
\text { Inhalation of gaseous and particulate } \\
\text { smelter emissions }\end{array}$ & $\begin{array}{l}\text { RESRAD-BUILD } \\
\text { RESRAD-BUILD } \\
\text { CAP88-PC }\end{array}$ \\
\hline Shallow burial of equipment & $\begin{array}{l}\text { External irradiation } \\
\text { Inhalation } \\
\text { Ingestion }\end{array}$ & $\begin{array}{l}\text { RESRAD } \\
\text { RESRAD } \\
\text { RESRAD }\end{array}$ \\
\hline
\end{tabular}

a Grove (1992).

b Yu et al. (1994).

c Yu et al. (1993).

d Reeves et al. (1986). SWIFT II was used to calculate contaminant concentrations in groundwater; exposure assumptions from the EPA (1991) were used to estimate doses for a residential scenario.

e EPA (1992). 


\section{PREVIOUS RELATED STUDIES}

Numerous studies have been conducted in the past five years evaluating various options for NORM management and disposal; those studies that are relevant to this dose assessment are summarized briefly in this section. These studies were reviewed to help identify suitable input parameters for use in this dose assessment. In some cases the input parameters used in these previous studies were deemed to be appropriate, on the basis of confirmatory information from industry representatives or published literature, and were adopted in this study. (This report references these sources for input parameters, as appropriate.) Because not all of the input parameters for the previous studies were used in this assessment, and because assessment methodologies differed, it is inappropriate to compare the results of the previous studies with the results of this study.

In May 1993, the EPA issued the third draft of its risk assessment characterizing the generation and disposal of NORM by a number of industrial processes, including oil and gas production (EPA 1993a). The report was intended to help the EPA determine whether diffuse NORM regulations need to be developed. This study assessed the radiological doses and risks resulting from the disposal of scale and sludge in uncovered waste piles for site workers, for persons who occupy the site after it is closed, for the critical population group, and for the general public. The study also assessed the risk for the critical population group and the general public due to smelting of NORM-contaminated equipment.

In March 1993, the EPA issued a draft preliminary risk assessment of management and disposal options for NORM-contaminated wastes and piping in Louisiana (EPA 1993b). The study, a cooperative effort between the EPA and the State of Louisiana, evaluated the risks associated with downhole encapsulation of NORM-contaminated wastes, several near-surface disposal options (e.g., landspreading, landfilling), and consumption of shellfish gathered from NORM-contaminated, produced-water discharge sites.

A study of NORM management and disposal options, sponsored by the API, analyzed the risk associated with disposing of NORM-contaminated scale, sludge, and equipment by a number of different disposal methods in different environmental settings (Baird et al. 1990). The study identified maximum concentrations of NORM that could be handled safely by each disposal alternative without exceeding any radiation exposure limits. Limits for radiation exposures were defined from exposure limit criteria developed for corresponding radiation from related sources. The disposal methods analyzed included landspreading, abandonment of surface pipe, burial with unrestricted site use, burial at commercial oil industry waste facility with dilution by other wastes, burial at licensed disposal facilities, burial in surface mines, disposal in a plugged and abandoned well, underground injection, hydraulic fracturing, and injection into salt dome cavities. For contaminated equipment, the disposal options analyzed also included release for general use in a dwelling and smelting. 
The Petroleum Environmental Research Forum sponsored a study to evaluate the feasibility of recycling NORM-contaminated equipment as scrap metal (Dehmel et al. 1992). This study assessed the radiation exposures and risks associated with handling, transporting, and smelting NORM-contaminated equipment. 


\section{EQUIPMENT CLEANING FACILITIES}

In the oil and gas industry, cleaning facilities have been established to remove scale and sludge from equipment taken out of service. The types of equipment that can be cleaned for reuse in the industry include piping and storage vessels. Other types of equipment (e.g., filters, pumps, screens) cannot be cleaned easily and must be disposed of intact. Not all equipment taken out of service is contaminated with NORM. In states with NORM regulatory programs, NORMcontaminated equipment must be cleaned separately from noncontaminated equipment at a licensed facility operated in compliance with stipulated worker health and safety protection standards. In states without NORM programs, it is possible that NORM-contaminated equipment is not handled any differently from noncontaminated equipment and that worker protection standards are less stringent than in states with regulatory programs.

The intent of this assessment is to evaluate reasonable maximum doses to workers cleaning contaminated equipment at a licensed ${ }^{12}$ facility. Worker doses at unregulated facilities are also discussed. For all scenarios modeled, the median concentrations of radium and its decay progeny in Table 1 were used. Conservative, upper bound doses were estimated for several of the scenarios by using the 75th-percentile concentrations for scale listed in Table 1.

\subsection{SCENARIOS, PATHWAYS, AND ASSUMPTIONS}

For this assessment, three types of facility workers were modeled: pipe cleaner, vessel cleaner, and storage yard worker. In addition, doses to a resident living adjacent to an equipment storage yard were estimated.

\subsubsection{Pipe Cleaner}

In states with NORM regulatory programs, most pipe cleaning is done by a wet cleaning process. This method employs a high-pressure water lance (hydrolaser) that sprays water at $15,000 \mathrm{lb} / \mathrm{in}^{2}{ }^{2}$ Two individuals are required to operate the hydrolaser. The front-hood operator guides the hydrolaser into place and activates the machine; the back-hood operator turns the pipe in place as it is being cleaned. Both workers operate behind hoods to prevent exposure to airborne emissions. In this assessment, the back-hood operator was modeled because this individual comes in contact with the contaminated pipes and is likely to have greater exposures. For the hydrolaser process, external irradiation was the only pathway modeled; inhalation and ingestion were not modeled

\footnotetext{
12 It was assumed that the licensed facility operates in compliance with the requirements of Louisiana's NORM regulatory program (LDEQ 1992). In Louisiana, workers at a licensed facility are regulated as radiation workers.
} 
because the cleaning operation is a closed system (i.e., done under a hood) and the potential for inhalation or ingestion is minimal. In addition, at a licensed facility, workers are required to wear half-face respirators, protective clothing, and face shields for all cleaning operations.

The industry also applies dry pipe-cleaning processes to remove scale from piping and tubing. Until recently, dry processes were widely employed to clean all types of piping, including some that may have contained NORM-contaminated scale. Dry methods entail using abrasive tools to mechanically remove scale from piping. Dry pipe-cleaning processes are not used frequently at licensed facilities, because they are not as efficient as the hydrolaser and because the potential for generation of airborne emissions is increased. It is possible that in states without NORM regulations, NORM-contaminated scale is removed by using dry processes and that workers do not wear respirators during these activities. In this assessment, worker doses related to the dry pipe-cleaning processes were modeled. The dose from external radiation was assumed to be the same as that for the hydrolaser process. Under the assumption that respiratory protection was not used, the inhalation and ingestion pathways were modeled for the dry pipe-cleaning processes to estimate worker doses resulting from inhalation of NORM-contaminated air particulates and incidental ingestion of removable contamination.

For the external dose calculations, a 915-cm-long pipe containing a uniform scale thickness of $0.65 \mathrm{~cm}$ was assumed. For this pipe, the mass of scale was estimated as almost $20 \%$ of the total pipe weight. The source activity concentration for one pipe was estimated to be $2.5 \times 10^{-5} \mathrm{Ci}$ total radium, based on the mass of scale contained in one pipe and the median total radium concentration in Table 1. A 3:1 Ra-226:Ra-228 ratio was assumed. The source was modeled as a cylindrical surface. The input parameters used to model the pipe cleaner scenarios are listed in the Appendix, Table A.1. The effect of receptor distance, thickness of shield (i.e., pipe wall), and the Ra-226:Ra-228 ratio on external doses for pipe cleaners were investigated in the sensitivity analysis.

For the inhalation pathway, the critical parameter is the concentration of respirable dust in the air (i.e., airborne dust-loading). This parameter is dependent on many factors, including ventilation and particle size distribution. Because measurements of airborne dust loading associated with the cleaning process are not available, screening level estimates were based on a value of $0.0001 \mathrm{~g} / \mathrm{m}^{3}$, which is representative of long-term average dust loading for a residential scenario (NRC 1992).

For the incidental ingestion pathway, the assumed ingestion rate was $0.00625 \mathrm{~g} / \mathrm{h}$, the recommendation for occupational workers (EPA 1991). This value is very conservative given that workers are normally trained to avoid incidental ingestion and also routinely wear gloves in the workplace. Doses estimated for the inhalation and ingestion pathways include ingrowth and decay over a one-year period. 


\subsubsection{Vessel Cleaner}

Vessels are classified as any equipment that is totally or almost totally enclosed. Vessels range in size from about $2 \times 2 \mathrm{~m}$ to $9 \times 4 \mathrm{~m}$ and frequently are cleaned for reuse or salvage. Cleaning the larger vessels requires confined space work; at licensed facilities, workers are required to wear a full-face respirator with supplied air and protective clothing for this type of work. Initially, these requirements were imposed to protect workers from hazards other than NORM (e.g., hydrocarbons); however, they also provide protection against inhalation and ingestion of NORM.

Doses from external exposure were modeled for a worker cleaning NORM-contaminated sludge from a large vessel requiring confined space work. The inhalation and ingestion pathways were not modeled, as workers typically are required to wear respiratory protection. The exposure time per vessel was assumed to be 10 hours, conservatively. Unlike the pipe cleaning scenario, it is unlikely that individuals spend most of their time cleaning vessels.

The source was assumed to have a cylindrical geometry. The input parameters used to model the storage-vessel-cleaner scenario are provided in Table A.2.

\subsubsection{Storage Yard Worker}

Items stored in the storage yard at a pipe cleaning facility typically include piping, vessels, miscellaneous equipment, and sealed drums of scale and sludge that have been recovered by the cleaning processes. These items generally are stored in the open environment, stacked on pallets. It was assumed that no refurbishing (including cutting) of the equipment is conducted in the storage yard, and therefore, it was assumed that the potential for airborne emissions is minimal. The likely pathways for this scenario include external gamma irradiation and inhalation of Rn-222.

For the storage yard worker, potential doses from external gamma exposures were calculated for a storage rack of pipes. The source was assumed to have a rectangular geometry. The source activity concentration was estimated by multiplying the total radium activity of scale contained in one pipe (as estimated for the pipe cleaner scenario) by the number of pipes that equal the height of a storage rack (i.e., 16). A 3:1 Ra-226:Ra-228 ratio was assumed. The average distance from the worker to the source was estimated to be $3 \mathrm{~m}$, because typically, direct contact with the pipes is limited and a fork lift is used to move and stack the pipes. The input parameters used to model the storage-yard-worker scenario are listed in Table A.3 The effects of receptor distance, shield thickness, and the 3:1 Ra-226:Ra-228 ratio on storage-yard-worker doses were investigated in the sensitivity analyses. 


\subsubsection{Resident Adjacent to Storage Yard}

Doses were estimated for a resident living adjacent to the storage facility described in Section 5.1.3. The likely exposure pathways for this scenario include external gamma irradiation and inhalation of $\mathrm{Rn}-222$. The resident was assumed to reside $100 \mathrm{~m}$ away from the storage facility. Doses were calculated on an annual basis, assuming an exposure duration of 8,760 hours. The calculations did not account for any shielding from the walls of the house. The input parameters used to model this scenario are listed in Table A.3.

\subsection{METHODOLOGY}

External doses for workers were calculated with the Microshield Version 4 computer code (Grove 1992). Microshield was designed to analyze shielding and estimate gamma radiation exposures, and it provides solution algorithms for 14 different source geometries. A variety of scenarios can be modeled by specifying user input parameters: source configuration; distance and orientation between source and receptor; dimensions and density of source; dimensions, locations, and orientations of intervening shields; material density of shield; and selection of buildup factor reference material. Microshield can also perform a sensitivity analysis to investigate the effect of parameter variation.

Screening-level calculations were performed to estimate potential inhalation and ingestion doses to workers, with the methodology in the RESRAD-BUILD computer code (Yu et al. 1994). For the radon pathway, a screening analysis was performed by using methodology from the RESRAD computer code (Yu et al. 1993) to investigate the potential doses from inhalation of radon to a worker and an adjacent resident. To calculate the concentration of radon in the workplace, the total inventory of Ra-226 stored on site was estimated by multiplying the median scale concentration in Table 1 by the total number of stored drums, which was assumed to be 200 . On the basis of these assumptions, the total Ra-226 inventory was estimated to be $4 \times 10^{-2} \mathrm{Ci}$. The emanation fraction for sludge, 0.2 (EPA 1993a), was used because it was assumed that some of the equipment stored in the yard would contain sludge; this value is larger than the emanation fraction for scale and, therefore, more conservative. The air flow dependent ratio, ${ }^{13} \chi_{\text {Outdoor }}$, as calculated by using the methodology from RESRAD (Yu et al. 1993), can be written as

$$
\chi_{\text {Outdoor }}=\frac{1}{2 H u \sqrt{A}}
$$

${ }^{13}$ The air flow dependent ratio is the ratio of the activity concentration (pCi/L) in air at one location to the rate of continuous release of activity at another location (picocuries per second). 
where $A$ is the area of the source (50 square meters $\left[\mathrm{m}^{2}\right]$ ), $H$ is the uniform mixing height ( $2 \mathrm{~m}$ ), and $u$ is the wind speed $(2 \mathrm{~m} / \mathrm{s})$. The ratio calculated from these parameters is $1.8 \times 10^{-5} \mathrm{~s} / \mathrm{L}$.

Because the RESRAD-BUILD computer code does not provide a methodology for calculating the air flow dependent ratio for an off-site receptor, the air flow dependent ratio for the adjacent resident scenario was calculated by using the methodology in the CAP88-PC computer code, developed by the EPA's Office of Radiation Programs (EPA 1992) for dispersion of a point ground release. The ratio was calculated by using the dispersion class D (i.e., neutral), assuming a distance of $100 \mathrm{~m}$ from the source and a wind speed of $2 \mathrm{~m} / \mathrm{s}$. These exposure parameters were chosen to represent a conservative scenario. The air flow dependent ratio calculated by using these parameters is $1.8 \times 10^{-6} \mathrm{~s} / \mathrm{L}$.

The radon concentration is calculated by multiplying the emanation fraction from scale by the decay constant, the total amount of Ra-226, and the air flow dependent ratio calculated above. This calculation is conservative because it does not account for factors that prevent radon gas from escaping, such as well-sealed covers on the drums.

\subsection{RESULTS}

A summary of the estimated doses related to activities at an equipment cleaning facility is provided in Table 3. Discussions of these results and the results of sensitivity analyses are provided in the following sections.

\subsubsection{Pipe Cleaner}

The results for the pipe cleaner scenario indicate that a full-time worker would receive an annual external dose of about $4 \mathrm{mrem}$, using the median source term concentrations and an assumed $\mathrm{Ra}-226: \mathrm{Ra}-228$ ratio of 3:1. The sensitivity of the model to the $\mathrm{Ra}-226: \mathrm{Ra}-228$ ratio was explored by assuming that all of the source activity was attributable to $\mathrm{Ra}-226$; the resulting dose increased to approximately $5 \mathrm{mrem} / \mathrm{yr}$. An upper bound of the total dose was estimated to be $25 \mathrm{mrem} / \mathrm{yr}$, using the 75th-percentile source term estimates.

Sensitivity analyses were also performed on shield thickness and distance from the source to the receptor; the results of these analyses are shown in Figures 4 and 5, respectively. Each figure depicts the total dose as well as the contribution from each radium isotope, including decay progeny D. As anticipated, an increase in shield thickness (i.e., the pipe wall) decreases the dose slightly (Figure 4). The distance from the source to the receptor was increased from 30 to $100 \mathrm{~cm}$, resulting in a $25 \%$ decrease in dose (Figure 5). 
TABLE 3 Summary of Doses Associated with Equipment Cleaning Facilities

\begin{tabular}{|c|c|c|c|}
\hline \multirow[b]{2}{*}{ Scenario } & \multirow[b]{2}{*}{ Pathway } & \multicolumn{2}{|c|}{ Annual Doses $(\mathrm{mrem})^{\mathrm{a}}$} \\
\hline & & Median & 75th-Percentile \\
\hline Pipe cleaner (wet processes) & External gamma & 4 & 25 \\
\hline Pipe cleaner (dry processes) ${ }^{b}$ & $\begin{array}{l}\text { External gamma } \\
\text { Ingestion } \\
\text { Inhalation } \\
\text { Total }\end{array}$ & $\begin{array}{c}4 \\
35^{\mathrm{c}} \\
\frac{11}{50}^{\mathrm{c}}\end{array}$ & $-_{\mathrm{d}}^{25}$ \\
\hline Vessel cleaner & External gamma & $5^{\mathrm{e}}$ & $-{ }^{d}$ \\
\hline Storage yard worker & External gamma & 40 & 220 \\
\hline Adjacent resident & External gamma & 0.2 & 1 \\
\hline
\end{tabular}

a All doses, except those calculated for the vessel cleaner, are based on a 2,000-hour exposure time.

b Assumes no respiratory protection was used.

c Dose calculations include ingrowth and decay over a one-year period.

d Doses were not calculated for the 75th-percentile concentration.

e Doses based on a 100-hour exposure time, assuming 10 vessels were cleaned in a year.

For workers performing dry pipe-cleaning processes without respiratory protection, the results for the inhalation calculations indicate that the annual dose to a worker breathing NORMcontaminated dust for 2,000 hours is approximately $11 \mathrm{mrem} / \mathrm{yr}$. Th- 228 contributes over $80 \%$ of the total dose. For these same workers, the potential dose from incidental ingestion of NORM was estimated to be $35 \mathrm{mrem} / \mathrm{yr}$, for which $\mathrm{Pb}-210$ and associated decay progeny contribute about $75 \%$ of the total dose. For workers who use dry pipe-cleaning processes without respirators, the total estimated dose is about $50 \mathrm{mrem} / \mathrm{yr}$. The results from ingestion of $\mathrm{Pb}-210$ may be overestimated, because the source term concentration was based on secular equilibrium and the half-life of $\mathrm{Pb}-210$ is relatively long (22 years). These doses represent screening-level estimates only. Due to the high degree of uncertainty associated with these estimates, doses were not presented for the 75thpercentile source term. Additional information about the dry pipe-cleaning processes (e.g., dust loading factors, worker practices) is required to further define these estimates. 


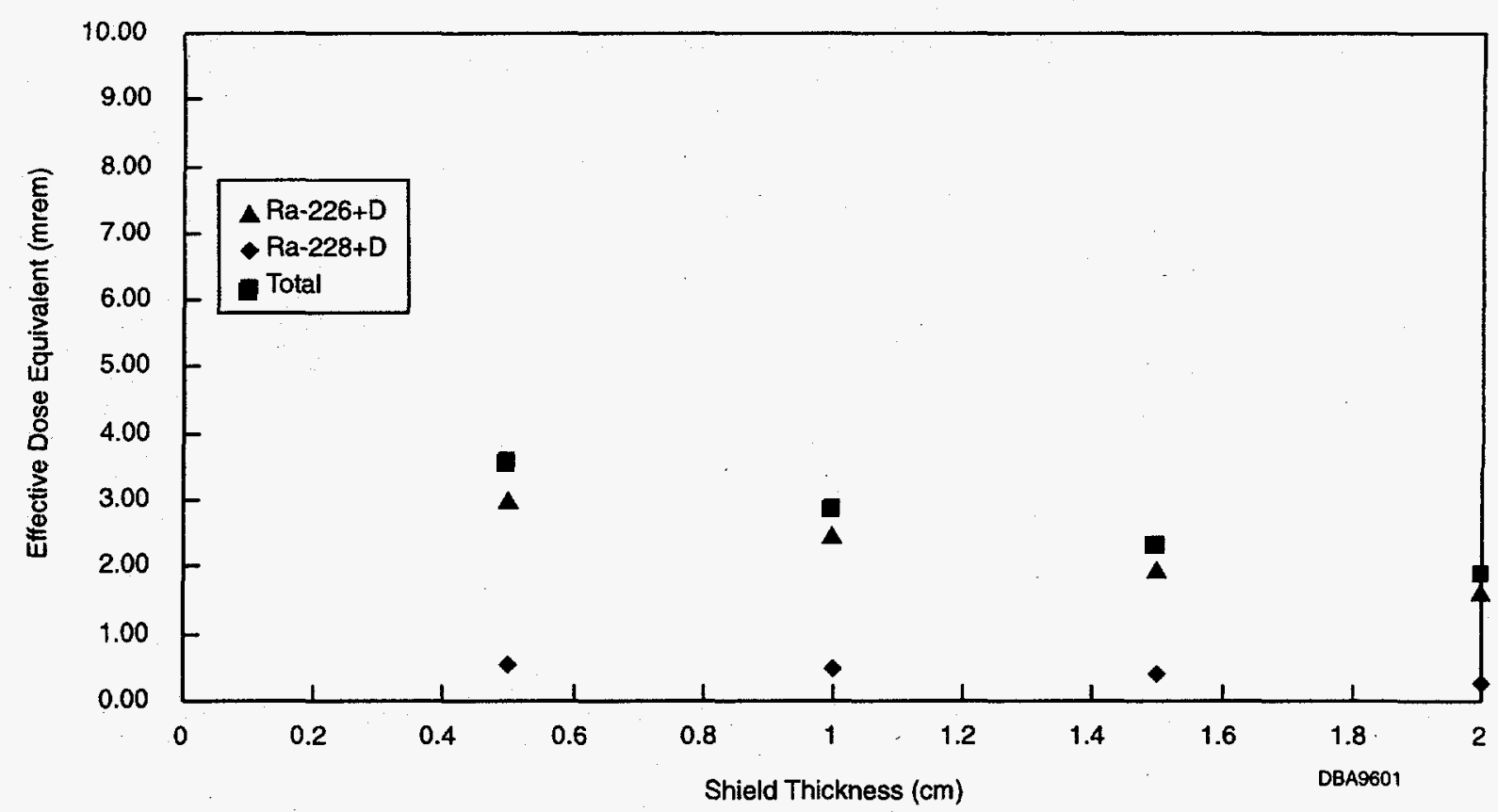

FIGURE 4 Pipe Cleaner Scenario Shield Thickness Sensitivity

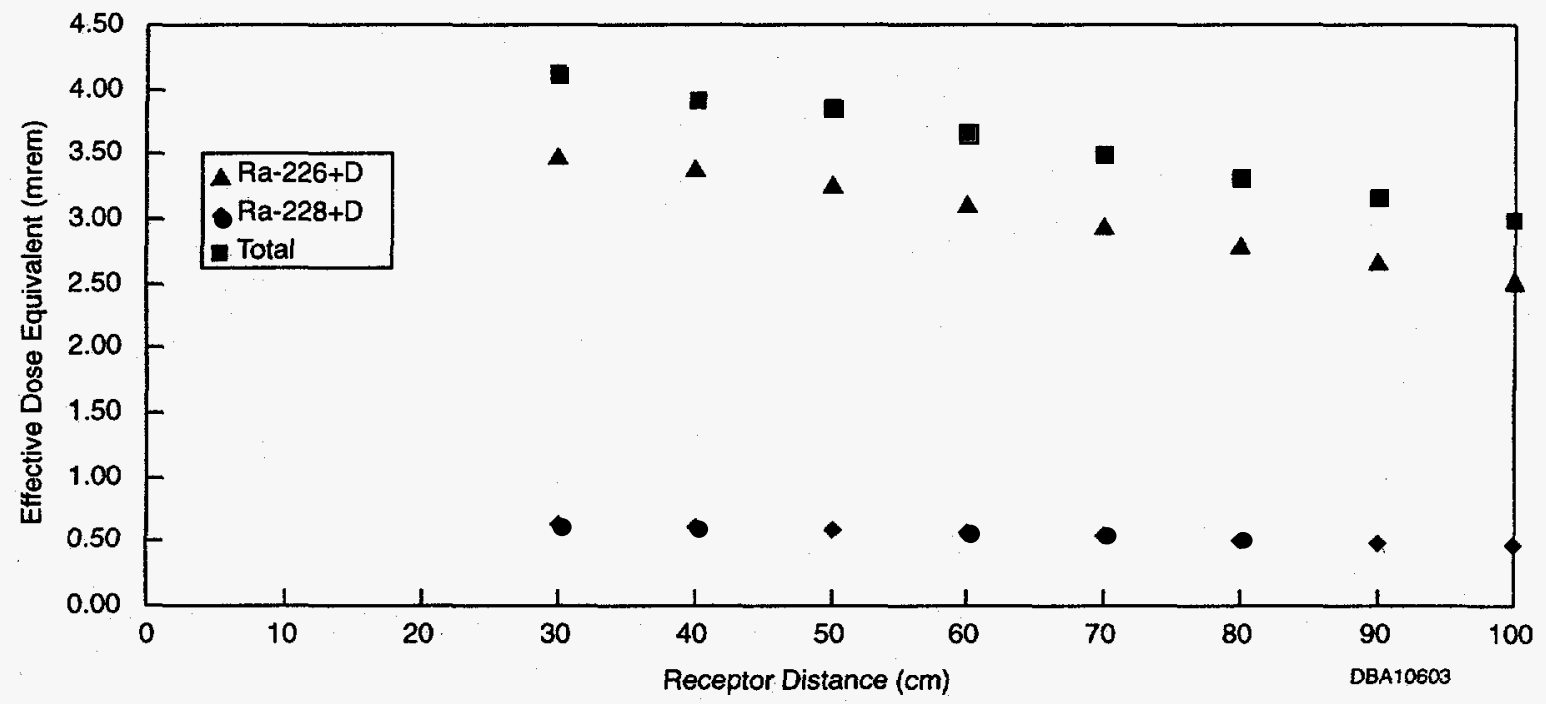

FIGURE 5 Pipe Cleaner Scenario Receptor Distance Sensitivity 


\subsubsection{Vessel Cleaner}

The external dose to a worker who cleans sludge out of a single large vessel was estimated to be $0.5 \mathrm{mrem}$ per vessel, assuming the median source term concentrations for sludge and a 10-hour exposure time. If the number of vessels cleaned per year is increased to 10 , a reasonable number according to industry representatives, the estimated annual dose would be $5 \mathrm{mrem}$, based on a maximum exposure duration of 100 hours. This estimate is conservative given that the worker's time inside the vessel is kept to a minimum; whenever feasible, most of the vessel cleaning is done remotely to limit exposure to the hydrocarbons. Inhalation and ingestion doses were not estimated for this scenario, because workers are required to wear full-face respirators with supplied air and protective clothing.

\subsubsection{Storage Yard Worker}

Results for the storage yard scenario indicate that a full-time worker would incur an annual external dose of about $40 \mathrm{mrem}$, assuming an average distance of $3 \mathrm{~m}$ from the source, the median source term concentrations for scale, a shield thickness of $1 \mathrm{~cm}$, and a Ra-226:Ra-228 ratio of 3:1. Decreasing the Ra-226:Ra-228 ratio from 3:1 to 1:0 increased the estimated dose to approximately $44 \mathrm{mrem} / \mathrm{yr}$. If the 75th-percentile source term estimates for scale are used, the resulting annual dose increased to approximately $220 \mathrm{mrem}$. Dose on contact with a pipe storage rack was estimated to be about $0.07 \mathrm{mrem} / \mathrm{h}$; however, direct handling of the pipe is expected to be limited to such activities as performing surveys.

Sensitivity analyses were performed on shield thickness and distance from the source to the receptor. Figure 6 presents results of the shield thickness sensitivity analysis; results are presented for a source distance of $1 \mathrm{~m}$. Varying the thickness of the pipe wall from 0.5 to $2 \mathrm{~cm}$ decreased the dose by approximately $60 \%$. The sensitivity analysis performed for receptor distance is depicted in Figure 7. The distance from the source to the receptor was varied from 100 to $1,200 \mathrm{~cm}$. The effective dose decreases to less than $10 \mathrm{mrem} / \mathrm{yr}$ at a distance of about $6.5 \mathrm{~m}$ from the source.

The incremental radon concentration in the storage yard was estimated to be on the order of $0.3 \mathrm{pCi} / \mathrm{L}$, which is a small fraction of the limit specified in DOE Order 5400.5 (DOE 1990) for radon concentrations in an uncontrolled area (i.e., $3 \mathrm{pCi} / \mathrm{L}$ ). The annual dose to a worker, based on a 2,000-hour exposure time, was estimated to be 0.009 working level months, ${ }^{14}$ which corresponds to about 9 mrem according to the dosimetric conversion factor recommended by the International Commission on Radiological Protection. (ICRP 1981).

\footnotetext{
14 Working level is a measure of the radioactivity of gases released by the decay of radon and is used as an expression of the radon exposure level for individuals. A working level month represents an individual's exposure to radioactivity resulting from the inhalation of radon-contaminated air equal to a concentration of one working level of radon decay products for one month (i.e, 170 hours).
} 


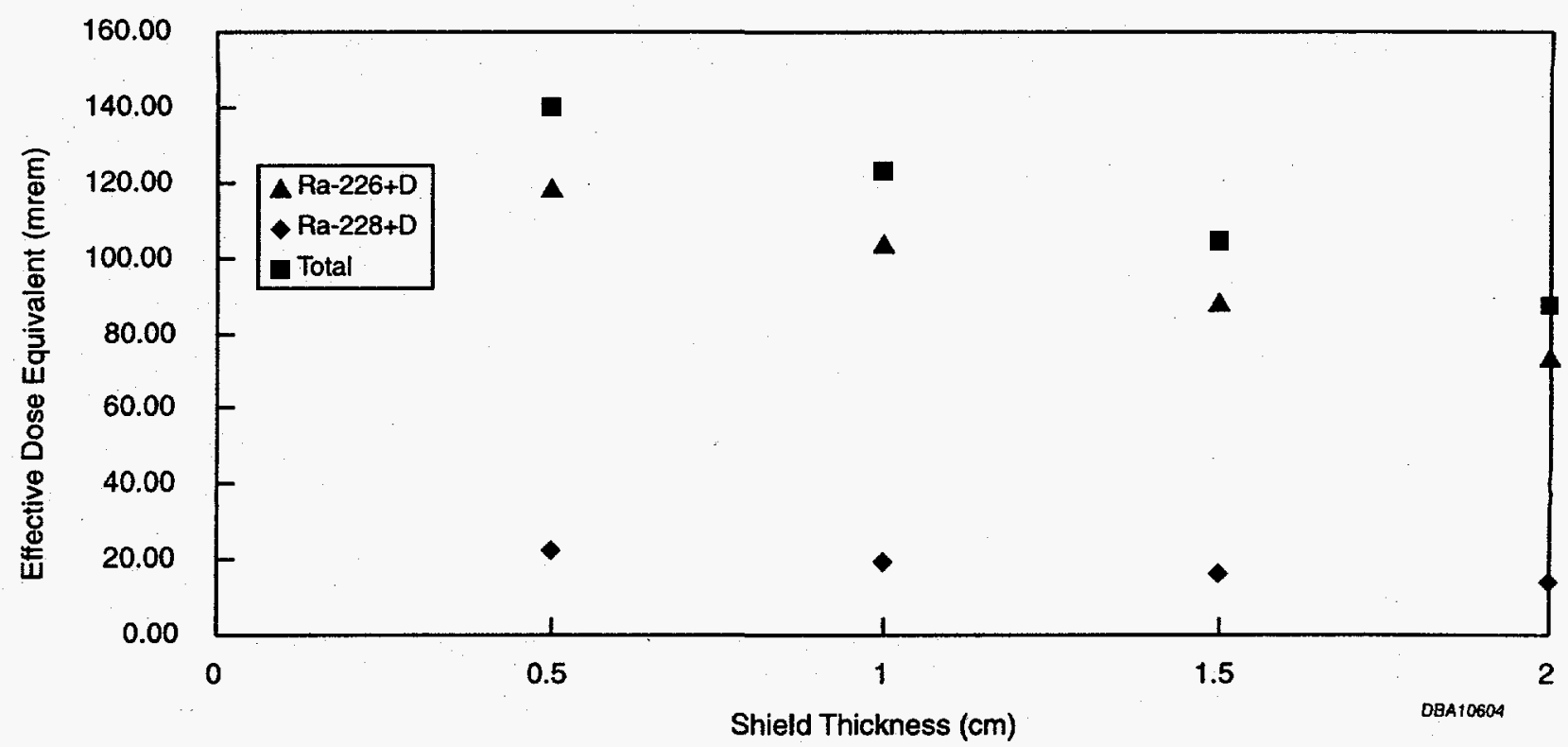

FIGURE 6 Storage Yard Worker Scenario Shield Thickness Sensitivity (source distance = 1 m)

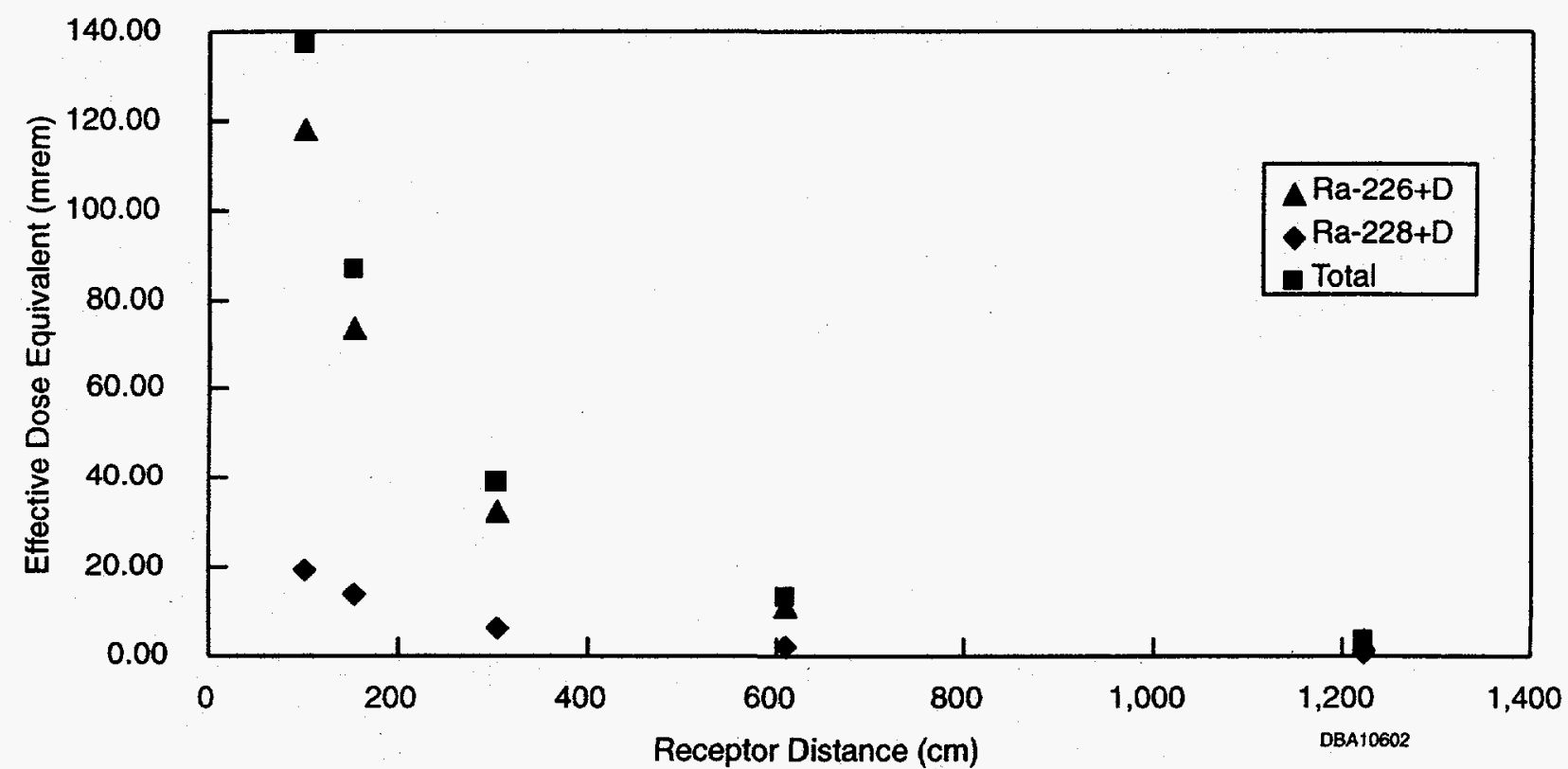

FIGURE 7 Storage Yard Worker Scenario Receptor Distance Sensitivity 


\subsubsection{Resident Adjacent to Storage Yard}

The estimated dose to the nearby resident from external irradiation was estimated to be about $0.2 \mathrm{mrem} / \mathrm{yr}$. This estimate is very conservative because it is based on full-time exposure ( 8,760 hours) and does not include shielding from the house walls. The annual dose to a nearby resident from inhalation of $\mathrm{Rn}-222$ was estimated to be approximately $4 \mathrm{mrem}$, based on the conservative assumptions used. 


\section{SUBSURFACE DISPOSAL METHODS}

\subsection{SCENARIOS AND PATHWAYS}

Subsurface disposal options include underground injection and downhole encapsulation. Underground injection is accomplished by injecting a slurry of NORM-contaminated wastes into a deep, subsurface formation. Downhole encapsulation entails placing NORM-contaminated scale, sludge, tubing, and other small pieces of equipment (e.g., valves, filters, screens) inside the casing of a well that is to be plugged and abandoned. After the material is in place, the wellbore is sealed with cement or grout to isolate the contaminated material. In this study, it was assumed that the depth of encapsulation is similar to the depth of injection. It was assumed also that the disposal depth is isolated vertically from a usable groundwater aquifer by such relatively impermeable, confining formations as shales. Conservative assumptions were made in running the models, thereby resulting in higher calculated contaminant concentrations at the receptor locations than would be expected under more realistic conditions.

Radium concentrations resulting from the underground injection and downhole encapsulation of NORM-contaminated wastes were estimated at several different receptor locations for a number of possible casing failure scenarios. The failure scenarios assumed casing failures in each of the geologic layers. These failures were assumed conservatively to release the entire volume of contaminated slurry into the geologic layer in which the failure occurred. It also was assumed conservatively that the NORM contained in the slurry dissolved instantaneously upon failure. Transport of the radionuclides was simulated for a 100,000-year period, which was far beyond the arrival times of interest.

To model the downhole encapsulation option, it was assumed that the encapsulated material was breached via a casing failure and that, upon failure, the radium dissolved instantaneously and moved horizontally into the geologic layer or vertically along the wellbore. It was also assumed that the entire volume of contamination moved into a single geologic formation. By making these extremely conservative assumptions, it was possible to use the model runs for underground injection to represent the failure scenarios for downhole encapsulation. If more realistic leaching times were assumed, it can be predicted that radionuclide concentrations resulting from casing failure would be lower at all receptor locations than those calculated for underground injection. Therefore, all scenarios simulated in this study are considered to represent both underground injection and downhole disposal activities, and no distinction is made between these two options in the rest of this discussion.

For the general public, the exposure pathway related to subsurface disposal of NORMcontaminated wastes is groundwater ingestion. In this study, it was assumed that the groundwater was extracted from a near-surface aquifer by a pumping well located at various distances from the 
disposal well. Table A.4 summarizes the assumptions and input parameters used to model the subsurface disposal scenarios.

\subsection{INPUT PARAMETERS}

\subsubsection{Geology}

A series of interlayered sandstone and shale formations were modeled as a generic site for subsurface disposal. This sequence is not representative of any particular area but rather was used to obtain an understanding of the transport mechanisms that could effect NORM injection. The model stratigraphy consisted of a top sandstone layer (approximately $550-\mathrm{m}$ thick) ${ }^{15}$ considered to be the source of groundwater at the receptor locations, underlain by alternating shale and sandstone layers, each about 490-m thick. The total stratigraphic sequence consisted of three sandstone and three shale layers. The layers were tilted, with a slope of 0.01 . The regional groundwater gradient ${ }^{16}$ also was assumed to be 0.01 . This gradient is large, although realistic, and gives conservative estimates for travel times and concentrations in the model. The slope and regional gradient were examined in sensitivity studies (see Section 6.4.3).

\subsubsection{Properties}

The sandstone hydraulic conductivity was assumed to be $3.5 \times 10^{-6} \mathrm{~cm} / \mathrm{s}$, and the shale hydraulic conductivity was assumed to be $3.5 \times 10^{-10} \mathrm{~cm} / \mathrm{s}$ (Domenico and Schwartz 1990). Longitudinal and transverse dispersivities ${ }^{17}$ were set at $305 \mathrm{~m}$ and $30 \mathrm{~m}$, respectively. These values are comparable to those suggested for sites of this size (Domenico and Schwartz 1990). Dispersivity is a means of incorporating geologic heterogeneity into a transport model.

The diffusion coefficients for both Ra-226 and Rn-222 were assumed to be $9.5 \times 10^{-7} \cdot \mathrm{m}^{2} /$ day in sandstone and $2.1 \times 10^{-7} \mathrm{~m}^{2} /$ day in shale. These coefficients are based on the

15 All measurements in this section have been converted from English to metric units.

${ }^{16}$ Groundwater gradient is a unitless number that measures the pressure drop across a distance. A gradient of 0.01 indicates a $1 \%$ change in head over a $1 \mathrm{ft}$ distance, or approximately $53 \mathrm{ft} / \mathrm{mi}$. Higher gradients cause flow to occur more rapidly.

17 Dispersivity is a measurement of mechanical mixing of a contaminant plume. It may be measured in the direction of groundwater movement (longitudinal) or perpendicular to the direction of groundwater movement (transverse). 
diffusion of radium in pure water and modified to give an effective diffusion coefficient according to the equation:

$$
D_{d}^{\prime}=\left(\frac{n}{2-n}\right)^{2} D_{d}
$$

where $D_{d}^{\prime}$ is the effective diffusion coefficient, $D_{d}$ is the diffusion coefficient in water at $25^{\circ} \mathrm{C}$, and $n$ is the porosity (Domenico and Schwartz 1990). The half-life for Ra-226 is 1,622 years and for $\mathrm{Rn}-222$ is 3.825 days (Cember 1988).

\subsubsection{Source Term}

To calculate the source term, it was assumed that 100,000 barrels (bbl) of NORM with a radium concentration of $2,000 \mathrm{pCi} / \mathrm{L}$ were injected over a period of four days. The total $\mathrm{Ra}-226$ in this slurry was calculated to be approximately $3.1 \times 10^{-5} \mathrm{~kg}$. A water volume of $4.5 \times 10^{6}$ liters per day accounted for the $100,000 \mathrm{bbl}$ of fluid injected.

\subsubsection{Casing Failure and Receptor Locations}

Casing failures were simulated at three different depths within the top aquifer: a shallow depth (approximately $90 \mathrm{~m}$ ), a depth at the midpoint (approximately $185 \mathrm{~m}$ ), and a depth near the bottom of the aquifer (approximately $275 \mathrm{~m}$ ). Failures were simulated in the center of each of the underlying geologic layers, at approximate depths of $790 \mathrm{~m}$ in shale; $1,280 \mathrm{~m}$ in sandstone; $1,770 \mathrm{~m}$ in shale; $2,745 \mathrm{~m}$ in sandstone; and $3,230 \mathrm{~m}$ in shale. Casing failure was simulated by injecting the entire Ra-226 source amount over a four-day period at each node point. No attempt was made to determine the well types or pressures needed to obtain these injection rates. Thus, it was not determined if this injection scenario is feasible or even possible. However, if this scenario is unfeasible, and longer time periods are required to inject the slurry, the result would be greater dilution of the plume and lower maximum concentrations.

Receptor points were located at $3.2 \mathrm{~km}$ upgradient from the disposal well; at the disposal well $(0 \mathrm{~km})$; and at $0.3,0.8,1.6,3.2,8,16,24$, and $32 \mathrm{~km}$ downgradient of the disposal well. All of the receptor points were located at an approximate depth of $90 \mathrm{~m}$ within the surface aquifer. Fractions of both Ra-226 and Rn-222 were measured at these sites over time. The upgradient receptor was used to evaluate the effects of diffusion in the model.

The model was run first to calculate the $\mathrm{Ra}-226$ and $\mathrm{Rn}-222$ concentrations at each of the receptor points described above. Then, assuming that two, pumping, municipal wells were located at the $0.3-\mathrm{km}$ and $0.8-\mathrm{km}$ receptor points, the model was run to calculate the Ra-226 and Rn-222 
concentrations at each of the receptor points again. These wells were assumed to pump simultaneously at $0.6 \mathrm{~L} / \mathrm{s}(10 \mathrm{gal} / \mathrm{min})$ for the entire 100,000-year time frame of the model.

\subsubsection{Numerical Implementation}

The conceptual site modeled was $16 \mathrm{~km}$ wide, $35 \mathrm{~km}$ long, and 3,050 $\mathrm{m}$ deep. An area of $35 \mathrm{~km}$ ( $X$ direction) by $8 \mathrm{~km}$ ( $Y$ direction) in the horizontal plane and $3,050 \mathrm{~m}$ in the vertical plane ( $Z$ direction) was discretized into a finite difference mesh with 40 divisions in the $X$ direction, 15 divisions in the $Y$ direction, and 8 divisions in the $Z$ direction (Figure 8). Because the model is symmetric about the $Y$ axis, a half-model was used.

Both horizontal boundaries in the $X$ direction were modeled as constant-head boundaries, a nonchanging condition to match regional aquifer characteristics. The horizontal boundaries in the $Y$ direction and the vertical $Z$ boundaries were modeled as no-flow boundaries. A groundwater gradient was induced by tilting the model to produce both stratigraphic and groundwater slopes of 0.01 , conservative values that lower the calculated travel times of a contaminant plume.

The source location for the NORM injection was located on the $Y=1$ boundary, to exploit symmetry, and approximately $3.2 \mathrm{~km}$ from the $X$ boundary. This location is to prevent the $X$ boundary from influencing upgradient diffusion and transport of the radionuclides. The mesh is finer near the source, which aids numerical stability and provides a higher resolution solution near the injection point and closest receptors.

\subsection{METHODOLOGY}

A groundwater flow and contaminant transport model was used to model underground injection and downhole encapsulation of NORM. The model assumed a generic geologic setting with conservative estimates of required parameters. The subsurface disposal methods were conceptually modeled with a casing failure in each of the geologic layers. It was assumed that during casing failure, the entire volume of NORM was released, a conservative but unlikely assumption. This modeling scenario was repeated for each geologic layer. For each scenario, radium concentrations were calculated at a number of receptor locations in a near-surface aquifer. In addition, the sensitivity of the model to pumping wells, regional groundwater gradients, hydraulic conductivities, mesh size, and radium concentration levels was explored.

The SWIFT II model (Reeves et al. 1986) was chosen for this assessment because (1) it is a three-dimensional model, (2) it calculates radionuclide transport with decay, and (3) it has been widely reviewed and validated. The SWIFT II code was developed to analyze coupled hydrologic, 


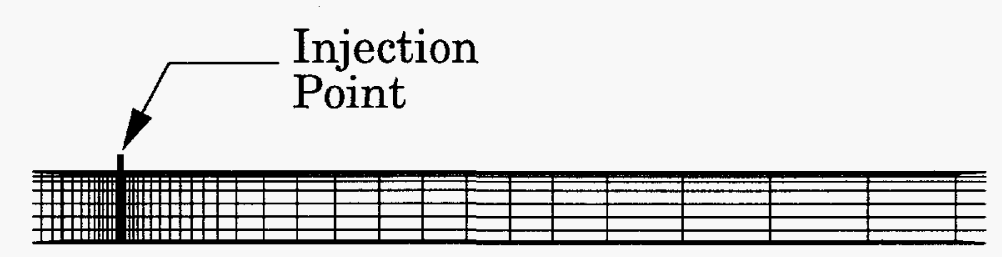

\section{Side View}

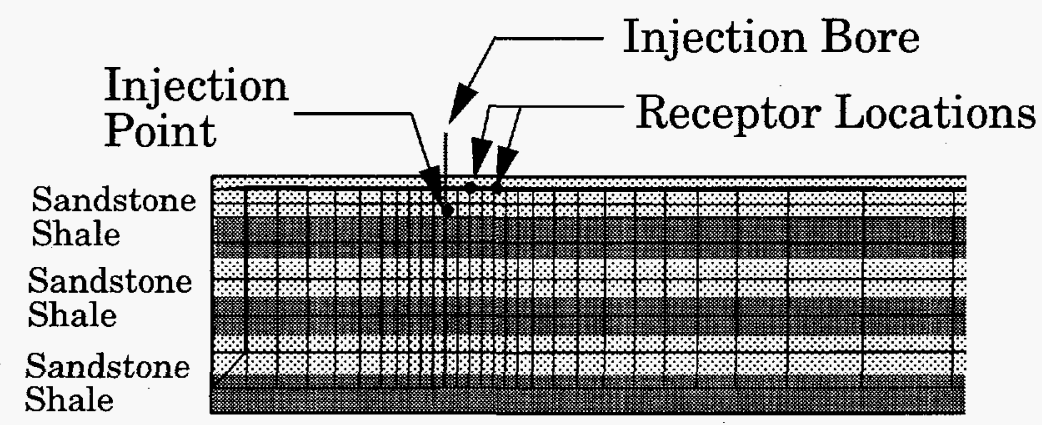

\section{Detail of Side View}

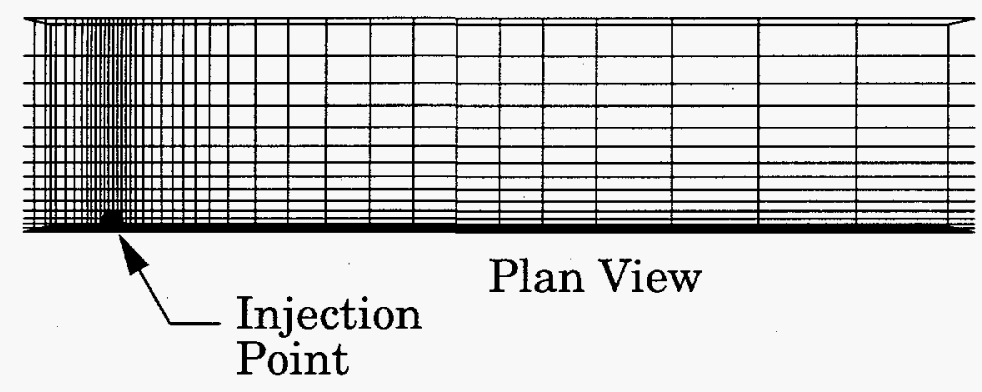

\section{FIGURE 8 Mesh Used in the SWIFT II Model}

thermal, density, dual-porosity, and solute transport processes in porous media by using a finite difference numerical model. The code has capabilities for simulating continuous and discontinuous layers, time-dependent and constant sources and sinks, and both transient and steady-state groundwater flow. The code also has several other capabilities that were not utilized in this study.

SWIFT II was configured to model the transport of Ra-226 and its first daughter product, $\mathrm{Rn}-222$, for each casing failure. The model calculated radionuclide concentrations in the units of grams of Ra-226 per grams of fluid. These concentrations were converted to picocuries per liter by dividing by $1 \times 10^{3} \mathrm{~g} / \mathrm{L}$. (One gram of Ra-226 has $3.7 \times 10^{10}$ disintegrations per second, which equals one curie; therefore, grams of Ra-226 per liter are equal to curies of Ra-226 per liter.) 
Annual doses resulting from ingestion of groundwater were calculated for each of the modeled scenarios by using exposure parameters recommended by the EPA for maximum residential exposures (EPA 1991). An individual was assumed to drink $2 \mathrm{~L}$ of water each day, 350 days per year.

\subsection{RESULTS}

Table 4 lists the estimated annual doses resulting from the ingestion of contaminated groundwater at each receptor point for each casing failure depth simulated. A worst-case scenario was simulated for each receptor point in which casing failure occurred at a depth of $90 \mathrm{~m}$ in the surface aquifer, which is the same depth as the receptor points. A more realistic, but still conservative, base-case scenario was also simulated for each of the receptors in which casing failure occurred at a depth of $275 \mathrm{~m}$ in the surface aquifer. The results of the worst-case and base-case scenarios are discussed below. All of the other failure scenarios (i.e., scenarios in which failure occurred at depths greater than $275 \mathrm{~m}$ ) resulted in extremely low predicted concentrations, at least four orders of magnitude below the base-case scenario concentrations; they are not discussed further in this report and are not presented in Table 4.

The calculated $\mathrm{Rn}-222$ concentrations for all scenarios were at least four orders of magnitude below those calculated for Ra-226. Because these concentrations are considered to be insignificant, they are not discussed in detail in this report.

\subsubsection{Worst-Case Scenario}

The worst-case scenario assumed that casing failure occurred at a depth of $90 \mathrm{~m}$, which is the same depth as all of the receptor points. For this scenario, the maximum calculated concentration, observed at the $0.3-\mathrm{km}$ receptor, was $1.3 \mathrm{pCi} / \mathrm{L} \mathrm{Ra}-226$ at approximately 700 years after failure. This concentration equates to approximately $1 \mathrm{mrem} / \mathrm{yr}$. In the worst-case scenario, the receptor located at the disposal well (i.e., the $0-\mathrm{km}$ receptor) was coincident with the failure point; therefore, the concentration would be equal to the source concentration of $2,000 \mathrm{pCi} / \mathrm{L}$. Potential doses at this receptor point for this scenario were not calculated. When the casing failure depth was set to $185 \mathrm{~m}$, just $95 \mathrm{~m}$ below the receptor, the maximum predicted concentration at the $0-\mathrm{km}$ receptor was $0.25 \mathrm{pCi} / \mathrm{L}$, equal to a dose of approximately $0.2 \mathrm{mrem} / \mathrm{yr}$.

\subsubsection{Base-Case Scenario}

The base-case scenario for this study assumed a casing failure at a depth of $275 \mathrm{~m}$, near the bottom of the surface aquifer. For this scenario, the model predicted a maximum concentration of 
TABLE 4 Summary of Doses from Ingestion of Groundwater

\begin{tabular}{|c|c|c|c|c|c|c|c|c|c|}
\hline \multirow{2}{*}{$\begin{array}{c}\text { Scenario } \\
\text { (failure depth) }\end{array}$} & \multicolumn{9}{|c|}{ Annual Dose at Each Receptor Location Relative to Disposal Well (mrem) } \\
\hline & $0.0 \mathrm{~km}$ & $0.3 \mathrm{~km}$ & $0.8 \mathrm{~km}$ & $1.6 \mathrm{~km}$ & $3.2 \mathrm{~km}$ & $8 \mathrm{~km}$ & $16 \mathrm{~km}$ & $24 \mathrm{~km}$ & $32 \mathrm{~km}$ \\
\hline Top aquifer $(90 \mathrm{~m})$ & $-{ }^{\mathbf{a}}$ & 1 & 0.2 & 0.01 & $\ll<^{b}$ & $\ll$ & $\ll$ & $\ll$ & $\ll$ \\
\hline Top aquifer (185 m) & 0.2 & 0.1 & 0.04 & 0.006 & $\ll$ & $\ll$ & $\ll$ & $\ll$ & $\ll$ \\
\hline Top aquifer $(275 \mathrm{~m})$ & 0.01 & 0.01 & 0.008 & 0.002 & $\ll$ & $\ll$ & $\ll$ & $\ll$ & $\ll$ \\
\hline Low conductivity ( $275 \mathrm{~m}$ ) & 0.01 & 0.01 & 0.003 & $\ll$ & $\ll$ & $\ll$ & $\ll$ & $\ll$ & $\ll$ \\
\hline High conductivity ( $275 \mathrm{~m}$ ) & 0.04 & 0.04 & 0.04 & 0.03 & 0.01 & 0.002 & $\ll$ & $\ll$ & $\ll$ \\
\hline Low gradient ( $275 \mathrm{~m})$ & 0.008 & 0.008 & 0.004 & $\ll$ & $\ll$ & $\ll$ & $\ll$ & $\ll$ & $\ll$ \\
\hline High gradient $(275 \mathrm{~m})$ & 0.03 & 0.03 & 0.03 & 0.02 & 0.007 & $\ll$ & $\ll$ & $\ll$ & $\ll$ \\
\hline Pumping wells (275 m) & 0.04 & 0.002 & 0.009 & 0.0008 & $<<$ & $\ll$ & $\ll$ & $\ll$ & $\ll$ \\
\hline Fine mesh $(275 \mathrm{~m})$ & 0.008 & $\begin{array}{l}0.01 \\
\text { at } 0.2 \mathrm{~km}\end{array}$ & $\begin{array}{c}0.004 \\
\text { at } 0.4 \mathrm{~km}\end{array}$ & $\ll$ & $\ll$ & $\ll$ & $\ll$ & $\ll$ & $\ll$ \\
\hline $\begin{array}{l}\text { Fine mesh with pumping } \\
\text { wells }(275 \mathrm{~m})\end{array}$ & 0.03 & $\begin{array}{l}0.02 \\
\text { at } 0.2 \mathrm{~km}\end{array}$ & $\begin{array}{r}0.0008 \\
\text { at } 0.4 \mathrm{~km}\end{array}$ & $\ll$ & $\ll$ & $\ll$ & $\ll$ & $\ll$ & $\ll$ \\
\hline $4,000 \mathrm{pCi} / \mathrm{L}(275 \mathrm{~m})$ & 0.02 & 0.03 & 0.02 & 0.004 & $\ll$ & $\ll$ & $<<$ & $\ll$ & $\ll$ \\
\hline
\end{tabular}

a This receptor is coincident with the failure point; therefore, the concentration is equal to the source concentration and potential doses from groundwater ingestion were not calculated.

b The symbol $<$ indicates a calculated concentration value below $1 \times 10^{-5} \mathrm{pCi} / \mathrm{L}$. 
$0.02 \mathrm{pCi} / \mathrm{L} \mathrm{Ra}-226$ at a depth of $90 \mathrm{~m}$ at the disposal well receptor, approximately 1,800 years after failure, and at the $0.3-\mathrm{km}$ receptor, approximately 3,600 years after failure. This concentration equates to an estimated dose of $0.01 \mathrm{mrem} / \mathrm{yr}$.

\subsubsection{Sensitivity Analyses}

Under the base-case scenario, when pumping wells were located at the $0.3-\mathrm{km}$ and $0.8-\mathrm{km}$ receptor points, the model predicted a maximum concentration of $0.05 \mathrm{pCi} / \mathrm{L} \mathrm{Ra}-226$ at the $0-\mathrm{km}$ receptor, which would result in a dose of approximately $0.04 \mathrm{mrem} / \mathrm{yr}$. The maximum values calculated at the pumping wells located at 0.3 and $0.8 \mathrm{~km}$ were $0.002 \mathrm{pCi} / \mathrm{L} \mathrm{Ra}-226,600$ years after failure, and $0.012 \mathrm{pCi} / \mathrm{L} \mathrm{Ra}-226,1,800$ years after failure, respectively. Calculated doses for these concentrations are approximately 0.002 and $0.009 \mathrm{mrem} / \mathrm{yr}$, respectively. The effect of installing pumping wells at these two locations was to (1) increase the vertical component of the contaminant migration, resulting in increased values at the $0-\mathrm{km}$ receptor and (2) increase dispersion of the contaminant plume, resulting in decreased values at the downgradient receptors. In addition, the installation of pumping wells decreases arrival times of the maximum concentration values at all receptors. The installed wells were pumped at a rate of $0.6 \mathrm{~L} / \mathrm{s}$ for the entire 100,000-year time frame of the simulation. The $0.6 \mathrm{~L} / \mathrm{s}$ rate was chosen as a reasonable maximum rate for a supply well in a material such as that specified for the surface aquifer.

Sensitivity calculations were performed for regional groundwater gradient and hydraulic conductivity. Both were raised and lowered one order of magnitude above and below the assumed value used for the model. For these sensitivity calculations, only the base-case scenario was modeled. Lowering the regional groundwater gradient or the hydraulic conductivity slightly lowered the calculated radionuclide concentrations at all of the receptors. Raising the hydraulic conductivities of the sandstone and the shale by one order of magnitude, to $3.5 \times 10^{-5}$ and $3.5 \times 10^{-9} \mathrm{~cm} / \mathrm{s}$ respectively, resulted in a maximum estimated dose, observed at the $0.3-\mathrm{km}$ receptor, of $0.04 \mathrm{mrem} / \mathrm{yr}$ (from $0.06 \mathrm{pCi} / \mathrm{L} \mathrm{Ra}-226$ ), approximately 100 years after failure. Increasing the regional groundwater gradient to 0.1 resulted in a maximum estimated dose, observed at the $0.3-\mathrm{km}$ receptor, of $0.03 \mathrm{mrem} / \mathrm{yr}$ (from $0.04 \mathrm{pCi} / \mathrm{L} \mathrm{Ra}-226$ ), approximately 200 years after failure.

The sensitivity of the model to the mesh size used was also explored. The mesh spacing was reduced by a factor of two, resulting in a spacing of approximately $76 \mathrm{~m}$ near the disposal well. Using this mesh, the closest receptor beyond the $0-\mathrm{km}$ receptor was located at $0.2 \mathrm{~km}$ downgradient. For this sensitivity analysis, two failure scenarios were considered: (1) the base-case scenario of failure in the surface aquifer at $275 \mathrm{~m}$ and (2) the base-case scenario with the addition of two pumping wells located at 0.2 and $0.4 \mathrm{~km}$ downgradient from the disposal well, pumping at $0.6 \mathrm{~L} / \mathrm{s}$. Under these conditions, the maximum estimated dose for the base-case scenario, observed at the $0.2-\mathrm{km}$ receptor, was $0.01 \mathrm{mrem} / \mathrm{yr}$ (from $0.01 \mathrm{pCi} / \mathrm{L} \mathrm{Ra}-226$ ). For the base-case scenario with 
pumping wells, the maximum estimated dose, observed at the $0-\mathrm{km}$ receptor, was $0.03 \mathrm{mrem} / \mathrm{yr}$ (from $0.04 \mathrm{pCi} / \mathrm{L} \mathrm{Ra}-226$ ).

The effect of higher contaminant concentration levels in the slurry was also investigated in the base-case scenario. Increasing the contaminant concentration from $2,000 \mathrm{pCi} / \mathrm{L}$ to $4,000 \mathrm{pCi} / \mathrm{L}$ Ra-226 doubled the resultant maximum concentrations with little observable effect on arrival times. Assuming concentrations or volumes much larger than those used in this assessment probably would not have major impacts on the estimated doses, particularly if more realistic assumptions about the casing failures and solubility of NORM were used. Baird et al. (1990) calculated significantly higher acceptable concentrations in their assessment of NORM injection. 


\section{LANDSPREADING WITH DILUTION}

In the past, surface spreading (landspreading) of scales and sludges recovered from production and processing equipment was a common method of disposal. Landspreading consists

of spreading scale and sludge over the soil surface to allow the hydrocarbon component of the waste to degrade. Frequently, the waste is mixed into the top layer of soil to dilute the contaminant concentrations. Sometimes, in the past, a single parcel of land was used repeatedly for waste disposal. Due to growing concerns over the potential for environmental contamination, states began implementing regulations that limited the hydrocarbon, metal, and salt contents of wastes that could be landspread. In states that have developed NORM regulations, landspreading NORMcontaminated scales and sludges either is no longer allowed or is permitted only if certain criteria (e.g., dilution to background plus $5 \mathrm{pCi} / \mathrm{g}$ or less, or dilution so that ambient exposure rate does not exceed $50 \mu \mathrm{R} / \mathrm{h}$ above background) are met. In states that do not have specific NORM regulatory programs, landspreading NORM wastes typically is unregulated.

In this assessment, the landspreading scenario was modeled conservatively by assuming residential use of land on which NORM had been disposed of. Residential land-use assumes that individuals live on the site; drink the groundwater or surface water; and produce most of their food on-site, including vegetables, milk, meat, and fish. These assumptions may not represent realistic future use of land currently used to dispose of NORM wastes by landspreading; however, these residential land-use assumptions are used consistently by risk assessors to evaluate the potential dose to a maximally exposed individual.

A range of resultant soil concentrations was modeled to represent various levels of dilution. As a worst-case scenario, a resultant soil concentration of $240 \mathrm{pCi} / \mathrm{g}$ total radium was assumed, based on the median source term for scale presented in Table 1 and a 100\% dilution factor. Given the current level of awareness in industry regarding NORM disposal issues, it is unlikely that a generator would knowingly landspread NORM waste to this high a concentration. However, such an event could have occurred in the past or, if a parcel of land was used repeatedly, NORM concentrations could have built up to such a level over time.

For comparison purposes, the resultant soil concentration was assumed to decrease to 30 and to $5 \mathrm{pCi} / \mathrm{g}$ total radium concentration. These concentrations were used because they bracket the limits established by existing state-level NORM regulations and the CRCPD Part $\mathrm{N}$ regulations for land being released for unrestricted use. In all existing state regulations, the limit for total radium in the upper $15 \mathrm{~cm}$ of soil is $5 \mathrm{pCi} / \mathrm{g}$. In Louisiana, Mississippi, and Texas, if the soil is known to 
have a radon flux ${ }^{18}$ less than $20 \mathrm{pCi} / \mathrm{g}$ per square meter per second, the limit for soil concentrations is $30 \mathrm{pCi} / \mathrm{g}$ total radium.

\subsection{METHODOLOGY AND INPUT PARAMETERS}

The landspreading scenario was modeled by using the RESRAD computer code (Yu et al. 1993). The RESRAD code is a pathways analysis code that implements the methodology prescribed in DOE Order 5400.5 (DOE 1990) for determining residual radioactive soil concentrations. The RESRAD analysis considers a residential scenario, in which a family is assumed to move onto the site, build a home, and raise crops and livestock for consumption. The pathways analyzed include external irradiation; inhalation of resuspended dust and radon; ingestion of crops, milk, and meat grown on the property; ingestion of fish from a nearby pond; ingestion of contaminated soil; and ingestion of surface water or groundwater.

For each of the three soil concentrations modeled in this study, an area of $4,050 \mathrm{~m}^{2}$ (1 acre) with a contaminated zone $20 \mathrm{~cm}$ thick was assumed. A Ra-226:Ra-228 ratio of 3:1 was assumed, and the decay progeny were assumed to be in secular equilibrium. It was assumed that the land was released for unrestricted use, at which time a family began living on the property. All pathways were considered in the analysis. For the radon pathway, a scale-specific, emanation coefficient factor of 0.05 was used (Baird et al. 1990; EPA 1993a,b). For the external irradiation pathway, a shielding factor of 0.6 was assumed to account for attenuation of gamma radiation by the walls of the house. RESRAD default values were assumed for all other input parameters, because they represent a generic facility and are intended to be conservative. The assumptions and input parameters used to model the landspreading scenarios are listed in Table A.5.

\subsection{RESULTS}

The total dose from all exposure pathways as a function of time for the three total radium concentrations is presented in Figure 9. For the worst-case concentration level (i.e., $240 \mathrm{pCi} / \mathrm{g}$ total radium), the estimated total dose for all pathways was on the order of 3,000 mrem/yr at the time the property was released. When the resultant soil concentration was lowered to $30 \mathrm{pCi} / \mathrm{g}$ and $5 \mathrm{pCi} / \mathrm{g}$, the estimated total dose for all pathways decreased to approximately 340 and $60 \mathrm{mrem} / \mathrm{yr}$, respectively. The results indicate that contamination of groundwater would occur after about 600 years, at which time the dose from ingestion of groundwater would be less than $10 \%$ of the initial total dose. ${ }^{18}$ Radon flux is the amount of radon crossing a specified surface within a specified time, measured in picocuries per
square meter per second. 
Figure 10 depicts the contribution to total dose from each pathway. The major contributor to dose was external gamma radiation, accounting for more than $80 \%$ of the total dose and occurring predominantly from the Ra-226 source concentration. The contribution from inhalation of Rn-222 is relatively low, around $1 \%$. When the $\mathrm{Rn}-222$ emanation coefficient was increased from 0.05 to 0.25 , a value that is consistent with the range of values for normal soils, the resulting dose for the baseline scenario increased by approximately $2 \%$.

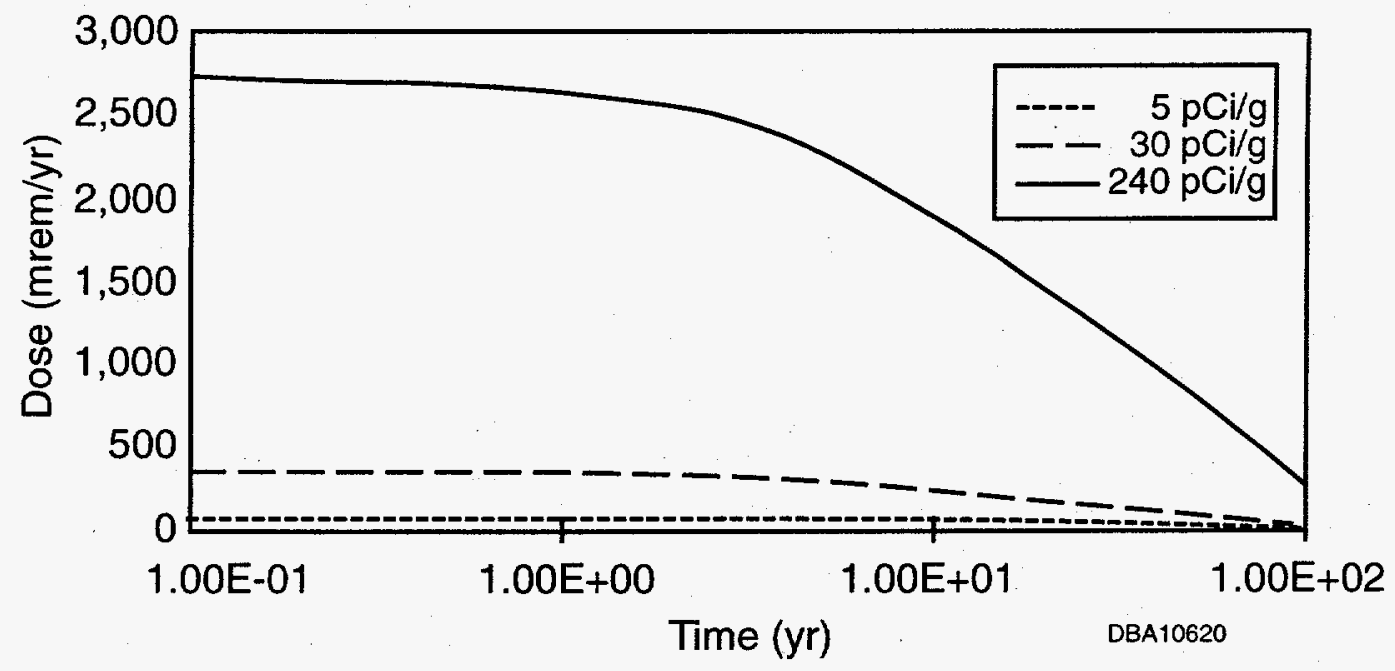

FIGURE 9 Total Dose over Time Summed over All Pathways for Landspreading with Dilution

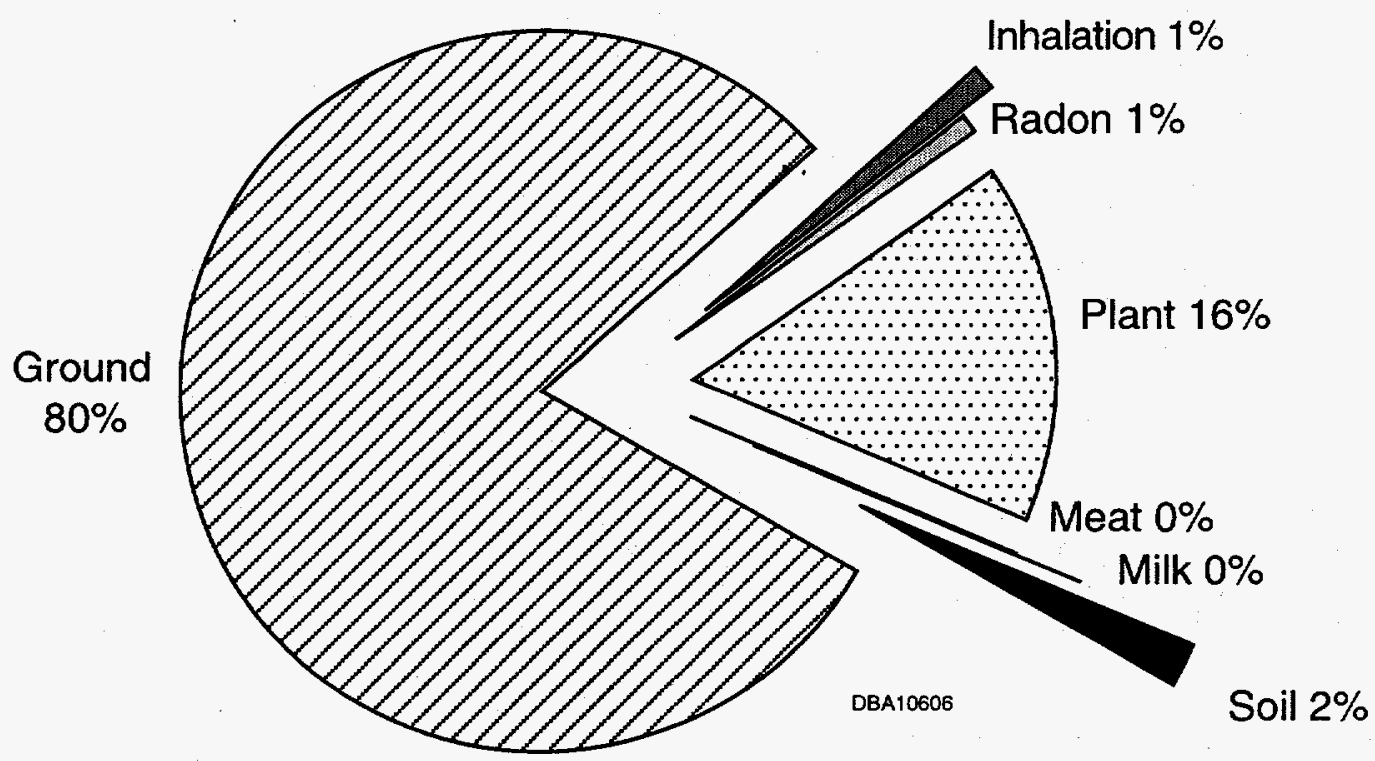

FIGURE 10 Comparison of Pathways for Landspreading with Dilution 


\section{SCRAP METAL RECYCLING OF CONTAMINATED EQUIPMENT}

Although smelting currently is not employed to dispose of NORM-contaminated equipment, it has been considered by the petroleum industry as a potentially viable disposal option. For equipment that cannot be easily cleaned and reused (i.e., scrap metal), smelting might be a preferable disposal option to landfilling or indefinite storage. The bulk of this scrap metal is likely to consist of scale-encrusted tubing that cannot be easily cleaned because of its small diameter. Other potential scrap items that could be sent to a smelter include filters, valves, pumps, and screens. Large storage vessels and piping are likely to make up only a small portion of the scrap metal stream, because only those items with an integrity failure would require disposal.

Due to the large quantities of scrap metal generated by the petroleum industry, recycling might be an attractive alternative if such a system could be implemented in a cost-effective manner, and if the risks associated with this option were demonstrated to be below an acceptable level. Human health risks from nonradiological hazards also would need to be assessed but are not included as part of this study. Currently, the industry does not have a system in place to handle the technical and political issues related to recycling contaminated scrap metal. The industry consists largely of individual generators, and a centralized scrap metal processing or storage facility is not available. The context under which a recycling program would be implemented involves many technical, sociological, and political issues, which are beyond the scope of this assessment.

For this assessment, potential radiological doses associated with smelting NORMcontaminated equipment were assessed, assuming that the scrap metal would be released from the point of generation directly to the steel mill under the existing network of operations. This assumption precludes the growing concern over radioactivity entering the steel industry and the political restraints existing in states where regulations have been promulgated. The focus of this study is the evaluation of potential doses from point of release through the melting process, and the evaluation of several end-point uses of both the metal and the slag product, on the basis of limited available information. Also investigated was the sensitivity of parameters that play key roles in estimating doses. The purpose of this study was not to derive release limits.

\subsection{SCENARIOS AND PATHWAYS}

The overall framework of exposure scenarios and assumptions was adopted from a methodology developed by Argonne National Laboratory to assess the radiological impacts to workers and the general public related to the recycling of radioactive scrap metal generated by DOE (Nieves et al. 1995). In using this methodology, the recycling process is divided into seven recycle steps, and representative exposure scenarios are considered for each step. The recycling steps evaluated to assess doses to commercial metal workers include the transportation of scrap metal from 
the place of origin to the smelter, the smelting process, the manufacture of industrial products, and the fabrication and distribution of end-use products. The exposure pathways evaluated include external irradiation, inhalation, and incidental ingestion. The end-use consumer scenarios were developed to model potential doses to the public associated with unrestricted reuse of recycled steel and slag. It was assumed that the recycled steel was used to manufacture an automobile and a piece of home furniture (a steel bed), and the slag by-product was incorporated into an asphalt parking lot. Restricted release of recycled steel back into the oil and gas industry also was evaluated, assuming that the metal was recycled into piping. The exposure pathway evaluated for the end-use scenarios is external irradiation. Public doses from inhalation of smelter emissions also were evaluated. For comparison purposes, the potential radiological dose to the public from unrestricted shallow burial of the NORM-contaminated scrap metal also was evaluated.

\subsection{METHODOLOGY}

Consistent with the methodology developed by Nieves et al. (1995), potential radiological doses were analyzed by using the RESRAD-BULD methodology (Yu et al. 1994). The RESRADBUILD computer code is a pathway analysis model designed to evaluate the potential radiological doses resulting from the decontamination and occupancy of buildings contaminated with radioactive material. This computer code was designed to be flexible, allowing for detailed modeling of the transport of contaminants in a building, coupled with a comprehensive exposure pathway analysis.

Potential radiological doses to the public from any emissions released during the melting process were assessed by using the CAP88-PC computer code, developed by the EPA's Office of Radiation Programs (EPA 1992). This code is a personal-computer version of the Clean Air Act Assessment Package-1988 (CAP-88) code (Beres 1990). The code comprises a set of subprograms, databases, and associated utility programs that implement a mathematical model for assessing dose and health risk from radionuclide emissions to the atmosphere. Environmental transport is modeled by using a modified Gaussian plume equation to estimate dispersion from the source. The code evaluates individuals residing at specific locations, as well as the collective population dose.

Doses from unrestricted shallow burial of NORM-contaminated scrap metal were assessed with the RESRAD computer code (Yu et al. 1993). The RESRAD code is a pathway analysis model that implements the methodology prescribed in DOE Order 5400.5 for determining residual radioactive material guidelines (DOE 1990).

\subsection{ASSUMPTIONS AND INPUT PARAMETERS}

Radiological impacts of recycling are dependent upon many factors, including the annual throughput, amount and concentration of specific radionuclide contaminants, dilution factor, 
radionuclide partition factors, and distribution of contaminated scrap in the steel industry. Because this information is not available, several conservative assumptions were made, based upon available data. Consequently, the results should be viewed as preliminary.

The input parameters used to calculate doses from the recycling of contaminated metal are presented in Tables A.6 and A.7; these values are consistent with those used by Nieves et al. (1995). The key assumptions in the analysis are discussed below.

\subsubsection{Scrap Metal Concentration}

The source term for NORM-contaminated scrap metal was based on the median concentrations in scale for radium and its decay progeny listed in Table 1, assuming a $\mathrm{Ra}-226: \mathrm{Ra}-228$ ratio of 3:1 and secular equilibrium. Discarded tubulars containing various amounts of NORM-contaminated scale were assumed to make up a large portion of the scrap metal. Large vessels also would be available for smelting; however, it was assumed that the sludge would have been removed from these vessels as part of a waste consolidation effort. Therefore, it was assumed that the scale source term would be most representative of contamination in the scrap metal. The total amount of scale contained within the scrap was estimated to be $5 \%$ of the total mass. The percentage of scale by weight in a tubular can reach up to $25 \%$ of the total mass; however, the equipment inventory includes various sizes and types of equipment and, therefore, $5 \%$ was selected as a reasonably conservative estimate. This estimate assumes no initial decontamination of equipment, other than removal of sludge from vessels. The sensitivities of these input parameters are discussed in the sensitivity analysis.

\subsubsection{Scrap Metal Inventory}

The estimated annual inventory of NORM-contaminated scrap nationwide is $172,800 \mathrm{t}$ (Section 2.5). A portion of the national inventory, 50,000 $\mathrm{t}$, was selected to represent a reasonable upper bound estimate of the annual throughput at a regional level.

\subsubsection{Partitioning Factors}

Radionuclide partitioning factors reflect the fraction of the original radionuclide concentration that ends up in the various end products of the steel smelting processes (e.g., ingots, slag) and in the work environment (e.g., dust, offgas). The radionuclides of interest for this study, heavy metals, are expected to partition with the slag by-product. Based on a literature review, the partitioning factors used for this study were assumed to be $0.1,0.005$, and 1 for the ingots, offgas, and slag, respectively (IAEA 1992; Hertzler 1993). These estimates are at the high end of the range 
provided in other studies; therefore, together they do not conserve mass. These estimates are supported by laboratory bench-scale tests performed to investigate the fate of NORM activity in steel mill furnaces (Dehmel et al. 1992). The results of the bench-scale tests indicated that about $98 \%$ of the added $\mathrm{Ra}-226, \mathrm{Ra}-228$, and $\mathrm{Th}-228$ was recovered in the slag regardless whether the conditions were oxidizing or reducing. The amount of activity partitioning to the steel was less than $2 \%$ of the initial activity. The partitioning of Ra-226 to the offgas was calculated to be $0.0004 \%$. Partitioning of $\mathrm{Pb}-210$ and $\mathrm{Po}-210$ were inconclusive.

\subsubsection{Dilution Factor}

Under realistic conditions, it is likely that NORM-contaminated scrap metal would be diluted with other steel sources at the mill. In terms of estimating dose, this parameter is critical, because dose is linearly proportionate to the dilution factor. The extent of dilution could vary considerably, depending on scrap metal inventories, furnace technology, scrap throughput, and mill capacity. The generation of scrap metal in the industry varies substantially and is controlled on a siteby-site basis. Therefore, it is unlikely that large quantities would enter the steel industry at one time. A dilution rate of 1:10 was applied to estimate dose; adjusting the dilution factor has a linear effect on the estimated dose.

\subsubsection{Smelter Emissions}

The potential dose to the maximally exposed individual from radioactive emissions during smelting was estimated. The annual release of radioactivity was estimated on the basis of a $50,000-t / y r$ throughput and the assumed partition factor to air. No dilution was assumed for the dose estimates. The efficiency of the baghouse filtration system was assumed to be $99.95 \%$ for particulate emissions. Radon emissions were based on $100 \%$ partitioning through the stack, with no filtration assumed. The CAP88-PC code was used with the following assumptions: a stack release height of $43 \mathrm{~m}$, stack exit velocity of $3 \mathrm{~m} / \mathrm{s}$, stack diameter of $6 \mathrm{~m}$, and typical U.S. Midwest weather conditions. These assumptions are consistent with the methodology developed by Nieves et al. (1995).

\subsubsection{Shallow Burial of Contaminated Equipment}

Disposal of NORM-contaminated scrap metal by unrestricted shallow burial was evaluated with the RESRAD computer code (Yu et al. 1993). It was assumed that a pile of scrap metal with a volume of $5,700 \mathrm{~m}^{3}$ was mixed with an equal volume of clean soil and then covered with a 0.5 -m-thick layer of clean soil. The burial site was assumed to have restricted access for 30 years, after which time it was released for unrestricted use. As a conservative estimate, residential land-use 
was assumed for the site. Individual doses were evaluated for a member of the public who builds a house on the property. A radon emanation coefficient of 0.05 for scale was assumed in the analysis (Baird et al. 1990; EPA 1993a). This parameter was investigated as part of the sensitivity analysis.

\subsection{RESULTS}

\subsubsection{Doses Associated with Recycling Scenarios}

A summary of the estimated doses projected for commercial metal workers for each recycling step is presented in Table 5. Annual doses were estimated on the basis of an exposure time of $2,000 \mathrm{~h} / \mathrm{yr}$ and a dilution factor of 1:10. The annual dose estimates range from $2 \times 10^{-3} \mathrm{mrem}$ (loader and warehouse worker) to $14 \mathrm{mrem}$ (slag worker). Predictably, the slag worker represents the constraining individual worker scenario. Under this scenario, doses are dominated by the external pathway. The major contributor to dose is Ra-226. The inhalation and ingestion pathways contribute less than $0.3 \%$ of the total dose.

Doses to the public from the use of products made of recycled steel and slag are also presented in Table 5, as are doses estimated for a petroleum industry worker who would be exposed to recycled pipes over a one-year period (i.e., 2,000 hours). Doses from the use of products released to the public result from external exposures to gamma radiation. The estimated doses for the public end-use scenarios are all on the order of $0.02 \mathrm{mrem} / \mathrm{yr}$, which is within the same magnitude as doses estimated for the petroleum industry worker (i.e., $0.03 \mathrm{mrem} / \mathrm{yr}$ ). The estimated doses presented are based on a dilution factor of 1:10.

\subsubsection{Doses to the Public from Smelter Emissions}

Dose estimates from smelting 50,000 $\mathrm{t}$ of NORM-contaminated scrap metal are presented in Table 6. Doses are presented for the maximally exposed individual, who is located approximately $500 \mathrm{~m}$ away from the stack release. The total dose from smelting 50,000 $\mathrm{t}$ of contaminated metal is estimated to be on the order of $4 \times 10^{-4} \mathrm{mrem} / \mathrm{yr}$. Doses to the maximally exposed individual from smelter emissions are estimated to be two orders of magnitude lower than doses estimated for other public end-use scenarios.

\subsubsection{Doses from Shallow Burial of Contaminated Equipment}

Individual dose estimates for unrestricted shallow burial of contaminated scrap metal are presented in Table 7. The total dose for a residential scenario was estimated to be about $80 \mathrm{mrem} / \mathrm{yr}$ 
TABLE 5 Summary of Annual Doses for the Recycling Scenarios ${ }^{a}$

\begin{tabular}{|c|c|c|c|}
\hline Receptor & Recycle Step & Scenario & $\begin{array}{l}\text { Individual Dose } \\
\text { (mrem/yr) }\end{array}$ \\
\hline \multirow[t]{2}{*}{ Worker } & \multirow[t]{2}{*}{ Scrap delivery } & Loader & $1 \times 10^{-1}$ \\
\hline & & Truck driver & $1 \times 10^{-1}$ \\
\hline Worker & Scrap processing & Processor & $4 \times 10^{-2}$ \\
\hline \multirow[t]{3}{*}{ Worker } & \multirow[t]{3}{*}{ Smelting } & Worker & $5 \times 10^{-3}$ \\
\hline & & Loader & $2 \times 10^{-2}$ \\
\hline & & Operator & $5 \times 10^{-2}$ \\
\hline \multirow[t]{5}{*}{ Worker } & \multirow[t]{5}{*}{ Industrial products } & Ingot caster & $5 \times 10^{-2}$ \\
\hline & & Small objects caster & $1 \times 10^{-1}$ \\
\hline & & Slag worker & $1 \times 10^{+1}$ \\
\hline & & Loader & $3 \times 10^{-2}$ \\
\hline & & Truck driver & $3 \times 10^{-2}$ \\
\hline \multirow[t]{3}{*}{ Worker } & \multirow[t]{3}{*}{ Initial fabrication } & Yard worker & $6 \times 10^{-3}$ \\
\hline & & Sheet worker & $9 \times 10^{-3}$ \\
\hline & & Coil worker & $4 \times 10^{-2}$ \\
\hline \multirow[t]{2}{*}{ Worker } & \multirow[t]{2}{*}{ Final fabrication } & Sheet worker & $8 \times 10^{-3}$ \\
\hline & & Coil worker & $4 \times 10^{-2}$ \\
\hline \multirow[t]{4}{*}{ Worker } & \multirow[t]{4}{*}{ Distribution } & Loader & $3 \times 10^{-2}$ \\
\hline & & Truck driver & $3 \times 10^{-2}$ \\
\hline & & Sheet worker & $8 \times 10^{-3}$ \\
\hline & & Warehouse worker & $2 \times 10^{-3}$ \\
\hline \multirow[t]{3}{*}{ Public } & \multirow[t]{3}{*}{ End-use } & Automobile & $2 \times 10^{-2}$ \\
\hline & & Home furniture (steel bed) & $2 \times 10^{-2}$ \\
\hline & & Parking lot (slag) & $2 \times 10^{-2}$ \\
\hline $\begin{array}{l}\text { Petroleum industry } \\
\text { worker }\end{array}$ & End-use & Pipe & $3 \times 10^{-2}$ \\
\hline
\end{tabular}

a Annual doses are based on an initial charge containing $5 \%$ by weight NORM-contaminated scale, nuclide partitioning factors, and a dilution factor of $1: 10$. Smelter worker scenarios are based on a throughput of 50,000 t per year. Ingrowth and decay are accounted for over a one-year period. 
TABLE 6 Summary of Annual Doses Associated with Radioactive Emissions from a Steel Smelting Facility

\begin{tabular}{|c|c|c|}
\hline Radionuclide $^{\mathrm{a}}$ & $\begin{array}{l}\text { Annual } \\
\text { Release Rate } \\
\text { (Ci) }\end{array}$ & $\begin{array}{l}\text { Annual Dose to Maximally } \\
\text { Exposed Individual } \\
\text { (mrem/yr) }\end{array}$ \\
\hline Lead-210 & $2.3 \times 10^{-6}$ & $1.9 \times 10^{-5}$ \\
\hline Radium-226 & $2.3 \times 10^{-6}$ & $6.5 \times 10^{-6}$ \\
\hline Radium-228 & $7.7 \times 10^{-7}$ & $8.5 \times 10^{-7}$ \\
\hline Thorium-228 & $7.7 \times 10^{-7}$ & $2.8 \times 10^{-5}$ \\
\hline Radon-222 & $9.0 \times 10^{-1}$ & $3.4 \times 10^{-4}$ \\
\hline \multicolumn{3}{|c|}{$\begin{array}{l}\text { Ingrowth and decay are accounted for over a one-year } \\
\text { period. }\end{array}$} \\
\hline \multicolumn{3}{|c|}{$\begin{array}{l}\text { Based on a } 50,000 \mathrm{t} / \mathrm{yr} \text { throughput containing } 5 \% \text { weight by } \\
\text { NORM scale, and radionuclide partitioning factors. No } \\
\text { dilution is assumed. }\end{array}$} \\
\hline \multicolumn{3}{|c|}{$\begin{array}{l}\text { The maximally exposed individual is located approximately } \\
500 \mathrm{~m} \text { from the stack. Doses account for an off-gas filtration } \\
\text { efficiency of } 99.95 \% \text { for particulates; no filtration is assumed } \\
\text { for radon. }\end{array}$} \\
\hline
\end{tabular}

at the time of release of the property (i.e., 30 years). The major contributor to dose is inhalation of radon. The sensitivity of the radon emanation coefficient parameter was investigated. Results indicated that varying this parameter by a factor of five would increase the dose linearly to $400 \mathrm{mrem} / \mathrm{yr}$. However, scale is a very dense material, and radon emanation is believed to be low (Baird et al. 1990; Wilson 1992). Additional studies to investigate this parameter would decrease the amount of uncertainty associated with estimating doses for this scenario.

\subsubsection{Sensitivity Analysis}

Because of the large degree of uncertainty related to the radionuclide source term concentrations and the amount of scale contained in the initial throughput, a sensitivity analysis was performed to show the relative effect of these parameters on the resulting dose. The sensitivity analysis was conducted for a range of scale inputs (i.e., $1-10 \%$ by weight of initial charge) and the median and 75th-percentile concentrations presented in Table 1. Estimated doses are presented in Figure 11 for the slag worker. The estimated doses ranged from 3 to $160 \mathrm{mrem} / \mathrm{yr}$. 
TABLE 7 Annual Public Individual

Doses for Unrestricted Shallow Burial of

NORM-Contaminated Scrap Metal

\begin{tabular}{|c|c|c|}
\hline \multirow[b]{2}{*}{ Radionuclide $^{\mathbf{a}}$} & \multicolumn{2}{|c|}{ Exposure Pathway } \\
\hline & $\begin{array}{l}\text { Inhalation } \\
\text { (mrem/yr) }^{b}\end{array}$ & $\underset{(\mathrm{mrem} / \mathrm{yr})^{b}}{\text { External }}$ \\
\hline Lead-210 & 0 & $1.6 \times 10^{-6}$ \\
\hline Radium-226 & $8.3 \times 10^{1}$ & $7.7 \times 10^{-1}$ \\
\hline Radium-228 & 0 & $2.4 \times 10^{-2}$ \\
\hline Thorium-228 & 0 & $1.1 \times 10^{-5}$ \\
\hline
\end{tabular}

a Ingrowth and decay are accounted for over a one-year period.

b Doses are based on disposal of 50,000 $t$ of scrap metal containing 5\% NORMcontaminated scale by weight distributed over $11,400 \mathrm{~m}^{2}$ and mixed with an equal quantity of soil. A residential scenario is assumed after 30 years of restricted access.

If smelting were to be implemented by the industry, it could be controlled to keep worker doses as low as possible, as is reflected in this analysis. By limiting the contamination level of the initial charge, the resultant slag concentrations could be controlled to a specified activity concentration. Because smelting concentrates almost all of the radionuclides of concern for NORM in the slag, controlling the activity levels in the slag might improve the feasibility of smelting as a disposal option. It also could provide greater flexibility in disposing of the slag and potentially relieve the industry of having to dispose of the slag at a regulated disposal facility. By minimizing the slag disposal costs, the industry could optimize the savings realized by recycling the steel. 


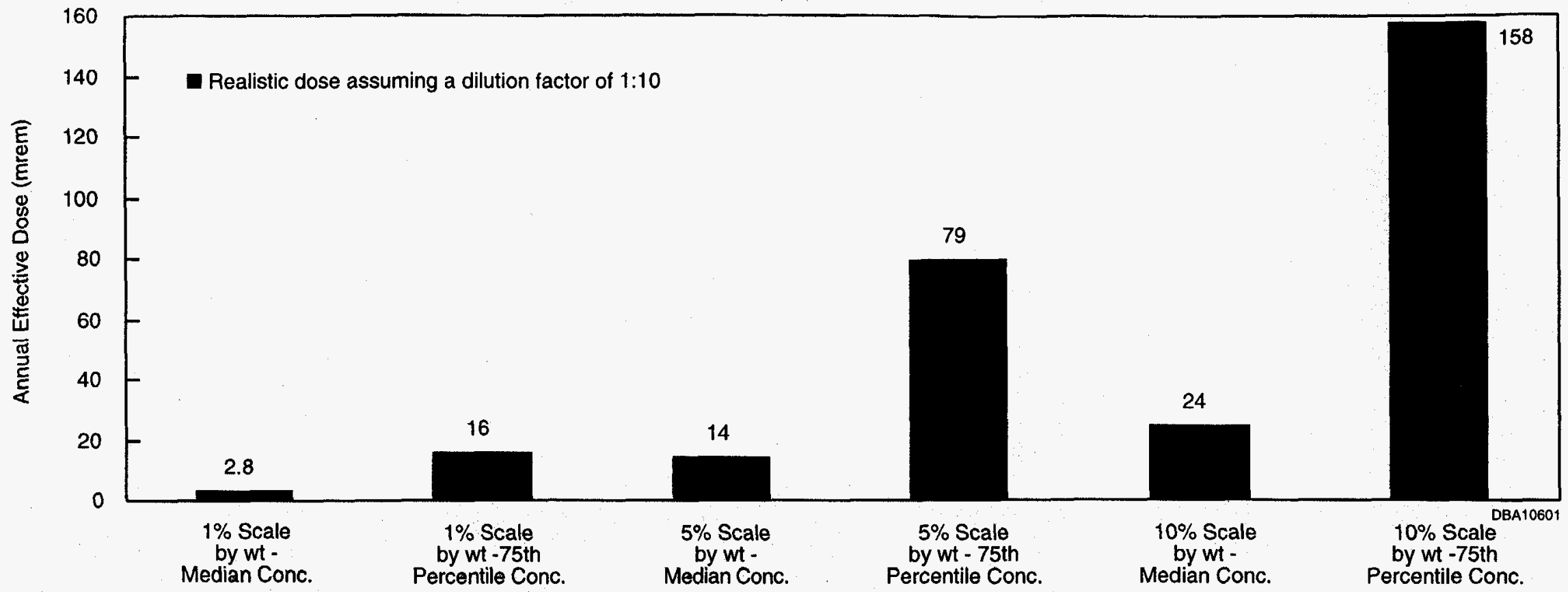

FIGURE 11 Sensitivity Analysis for the Slag Worker (constraining scenario) 


\section{CONCLUSIONS AND RECOMMENDATIONS}

\subsection{CONCLUSIONS}

The results of this assessment provide estimated annual doses to workers and the general public related to six NORM management and disposal methods: equipment decontamination, underground injection, downhole encapsulation, landspreading with dilution, smelting contaminated equipment, and unrestricted shallow burial of contaminated equipment. These results must be regarded as preliminary because adequate data describing the source term and other input parameters are not available. Absolute health risks cannot be determined from these preliminary estimates because of the uncertainty related to the source term concentrations and because of the conservative nature of many of the input assumptions. For the same reasons, conclusions about risk to human health should not be drawn by comparing the estimated doses with existing or proposed regulatory standards, such as dose limits and drinking water standards (Section 1.2).

Given these limitations, it is still possible to draw some general conclusions regarding the selected NORM management and disposal methods and to compare the estimated doses as a preliminary indication of the relative risks associated with each method. The existing regulated standards can be used to provide a benchmark value that adds perspective to the results. The following conclusions can be drawn on the basis of the results of this assessment:

- External exposures are roughly equivalent for workers at licensed and at unregulated equipment cleaning facilities: in the range of $4 \mathrm{mrem} / \mathrm{yr}$. However, the potential dose to workers from inhalation or ingestion of NORM particulates may be greater for workers at unregulated facilities, where respirators and protective clothing may not be used during dry pipe-cleaning operations. Preliminary estimates indicate annual doses of approximately $46 \mathrm{mrem}$ from the inhalation and ingestion pathways combined. Additional information about the dry pipe-cleaning processes (e.g., dust loading factors, worker practices) and the source term are needed to fully quantify the potential doses related to the inhalation and ingestion pathways.

- The results suggest that subsurface disposal of NORM-contaminated wastes in volumes less than $100,000 \mathrm{bbl}$ result in very low levels of Ra-226 in the groundwater, well below the $20 \mathrm{pCi} / \mathrm{L}$ regulatory limit for $\mathrm{Ra}-226$ in drinking water. The estimated doses to the general public associated with casing failures during underground injection of NORM-contaminated wastes are higher than those associated with casing failures during downhole encapsulation. However, the estimated doses associated with either subsurface disposal method appear to be so low (i.e., $\leq 1 \mathrm{mrem} / \mathrm{yr}$ ), even for failures that 
occur in the drinking water aquifer, that risk to the general public from either method is negligible.

- Assuming conservative residential land-use (i.e., individuals living and growing their own food on-site), landspreading with dilution presents the highest potential dose to the general public, on the order of 3,000 mrem/yr in the worst-case scenario, of all of the methods assessed in this study. External irradiation, which contributes $80 \%$ of the total dose, is the exposure pathway of greatest concern. Arguments that the radium is virtually immobile in natural soils cannot be used to justify landspreading as a safe disposal method for NORM-contaminated wastes. While the relative immobility of radium in soils may be protective of groundwater, the other exposure pathways result in a total dose that is unacceptable.

- Estimated doses to the general public from both smelter stack emissions and use of products made from recycled steel and slag are lower by at least two orders of magnitude than estimated doses related to unrestricted shallow burial of the same quantity of NORM-contaminated equipment.

\subsection{RECOMMENDATIONS}

The following studies and potential policy actions are recommended:

- NORM wastes generated by the petroleum industry should be further characterized to improve efforts to assess potential doses to workers and the general public. Further characterization of the source term concentration is particularly important. Existing data collected at the state and company levels should be aggregated to improve efforts to calculate statistically representative source term concentrations.

- Provided further assessment supports the results of this study indicating that subsurface disposal methods constitute realistically safe methods for disposing of NORM-contaminated wastes, state regulatory agencies should be encouraged to permit subsurface disposal projects more readily. Underground injection projects should not be considered to pose a significantly greater risk to the general public than downhole encapsulation projects. Regulators should strive to educate the public about the realistic risks related to subsurface disposal so that unfounded fears do not complicate the permitting process. 
- Further assessment of the potential radiological doses to the general public resulting from landspreading with dilution is needed to fully evaluate this disposal alternative.

- Because this study did not consider the political, economic, sociological, and nonradiological issues related to smelting NORM-contaminated equipment generated by the petroleum industry, further study is needed to fully examine the feasibility of this disposal option. 


\section{REFERENCES}

American Petroleum Institute, 1992, Bulletin on Management of Naturally Occurring Radioactive Materials (NORM) in Oil and Gas Production, API Bulletin E2, Washington, D.C.

API: see American Petroleum Institute.

Baird, R.D., et al., 1990, Management and Disposal Alternatives for NORM Wastes in Oil Production and Gas Plant Equipment, prepared for American Petroleum Institute, Dallas, Texas.

Beres, D.A., 1990, The Clean Air Act Assessment Package-1988 (CAP-88) - A Dose and Risk Assessment Methodology for Radionuclide Emissions to Air, Volumes 1, 2, and 3, SC\&A, Inc., McLean, Va.

Cember, H., 1988, Introduction to Health Physics, Second Edition, Pergamon Press, New York, N.Y.

Conference of Radiation Control Program Directors, Inc., 1994, Part N Regulation and Licensing of Naturally Occurring Radioactive Materials (NORM), SR-5 Committee, Frankfort, Ky.

CRCPD: see Conference of Radiation Control Program Directors, Inc.

Dehmel, J.C., et al., 1992, Scrap Metal Recycling of NORM Contaminated Petroleum Equipment, prepared for Petroleum Environmental Research Forum, Ponca City, Okla.

DOE: see U.S. Department of Energy.

Domenico, P.A., and F.W. Schwartz, 1990, Physical and Chemical Hydrogeology, John Wiley and Sons, New York, N.Y.

EPA: see U.S. Environmental Protection Agency.

Fisher, J.B., and M. Hammond, 1994, "Characterization of NORM Vessel Solids," Environmental Issues and Solutions in Petroleum Exploration, Production and Refining, Proc. International Petroleum Environmental Conf., University of Tulsa and PennWell Books, Houston, Texas.

Grove Engineering Inc., 1992, MicroShield 4 User's Manual, Rockville, Md.

Hertzler, T., et al., 1993, Recycle of DOE Radiologically Contaminated Metal - A Scoping Study, Draft, Science Application International Corp., Idaho Falls, Idaho. 
IAEA: see International Atomic Energy Agency.

ICRP: see International Commission on Radiological Protection

International Atomic Energy Agency, 1994, Clearance Levels for Radionuclides in Solid Materials: Application of Exemption Principles, IAEA Safety Series No. 111.G-1-5, Draft, Vienna, Austria.

International Commission on Radiological Protection, 1975, Report of the Task Group on Reference Man, ICRP Publication 23, Pergamon Press, New York, N.Y.

International Commission on Radiological Protection, 1981, Limits for Inhalation of Radon Daughters by Workers, ICRP Publication 32, Vol. 6, No. 1, Pergamon Press, Oxford, United Kingdom.

International Commission on Radiological Protection, 1991, 1990 Recommendations of the International Commission on Radiological Protection, ICRP Publication 60, Pergamon Press, Oxford, United Kingdom.

LDEQ: see Louisiana Department of Environmental Quality.

Loudermilk, M.D., 1994, personal communication from Loudermilk (Exploration and Production Department, American Petroleum Institute, Dallas, Texas) to K.P. Smith (Argonne National Laboratory, Lakewood, Colo.), Dec. 7.

Louisiana Department of Environmental Quality, 1992, Regulation and Licensing of NaturallyOccurring Radioactive Materials (NORM), Title 33 Environmental Quality, Part XV, Radiation Protection.

Minnaar, D., 1994, personal communication from Minnaar (Division of Radiological Health, Michigan Department of Public Health, Lansing Mich.) to K.P. Smith (Argonne National Laboratory, Lakewood, Colo.), Aug. 30.

Nieves, L.A., et al., 1995, Evaluation of Radioactive Scrap Metal Recycling, ANL/EAD/TM-50, Argonne National Laboratory, Argonne, Ill.

NRC: see U.S. Nuclear Regulatory Commission.

Otto, G.H., 1989, A National Survey on Naturally Occurring Radioactive Materials (NORM) in Petroleum Producing and Gas Processing Facilities, prepared for American Petroleum Institute, Dallas, Texas. 
Reeves, M., et al., 1986, Theory and Implementation for SWIFT II: The Sandia Waste-Isolation Flow and Transport Model for Fractured Media, Release 4.84, Sandia National Laboratory, NUREG/CR-3328, SAND83-1 159, Contract No. DE-AC04-76DP00789.

Snavely, E.S., 1989, Radionuclides in Produced Water - A Literature Review, American Petroleum Institute Publication No. 4504, Dallas, Texas.

U.S. Department of Energy, 1990, Radiation Protection of the Public and the Environment, DOE Order 5400.5, Washington, D.C.

U.S. Environmental Protection Agency, 1991, Risk Assessment Guidance for Superfund, Volume I: Human Health Evaluation Manual, Interim Final, EPA/540/R-92/003, Office of Emergency and Remedial Response, Washington, D.C.

U.S. Environmental Protection Agency, 1992, User's Guide for CAP88-PC, Version 1.0, 402-B-92-001, Office of Radiation Programs, Las Vegas, Nev.

U.S. Environmental Protection Agency, 1993a, DRAFT Diffuse NORM - Waste Characterization and Preliminary Risk Assessment, Office of Radiation and Indoor Air, Washington, D.C.

U.S. Environmental Protection Agency, 1993b, A Preliminary Risk Assessment of Management and Disposal Options for Oil Field Wastes and Piping Contaminated with NORM in the State of Louisiana - Peer Review Draft, Office of Radiation and Indoor Air, Washington, D.C.

U.S. Environmental Protection Agency, 1994, Drinking Water Regulations and Health Advisories, EPA 822-R-94-001, Office of Water, Washington, D.C.

U.S. Nuclear Regulatory Commission, 1992, Residual Radioactive Contamination from Decommissioning: Volume 1, Technical Basis for Translating Contamination Levels to Annual Total Effective Dose Equivalent, NUREG/CR-5512, Washington, D.C.

Wilson, A.J., and L.M. Scott, 1992, "Characterization of Radioactive Petroleum Piping Scale with an Evaluation of Subsequent Land Contamination," Health Physics 63:681-685.

Yu, C., et al., 1993, Manual for Implementing Residual Radioactive Material Guidelines Using RESRAD, Version 5.0, ANL/EAD/LD-2, Environmental Assessment Division, Argonne National Laboratory, Argonne, Ill.

Yu, C., et al., 1994, RESRAD-BUILD: A Computer Model for Analyzing the Radiological Doses Resulting from the Remediation and Occupancy of Buildings Contaminated with Radioactive Material, ANL/EAD/LD-3, Environmental Assessment Division, Argonne National Laboratory, Argonne, Ill. 
APPENDIX:

TABLES OF ASSUMPTIONS AND INPUT PARAMETERS 
TABLE A.1 Assumptions and Input Parameters Used to Model the Pipe Cleaner Scenarios

\begin{tabular}{llll}
\hline \multicolumn{1}{c}{ Parameter } & \multicolumn{1}{c}{ Units } & \multicolumn{1}{c}{ Value } & Reference $^{\mathrm{a}}$ \\
\hline Total radium & $\mathrm{pCi} / \mathrm{g}$ & 480 (median) & EPA (1993a) \\
concentrations, scale & & 2,700 (75th-percentile) & \\
Ra-226:Ra-228 & unitless & $3: 1^{\mathrm{b}}$ & Baird et al. (1990), \\
& & & EPA (1993a, 1993b) \\
Pipe length & $\mathrm{cm}$ & 915 & \\
Pipe diameter & $\mathrm{cm}$ & 15 & \\
Pipe wall thickness & $\mathrm{cm}$ & $1^{\mathrm{c}}$ & \\
Density of pipe & $\mathrm{g} / \mathrm{cm}^{3}$ & 7.86 & \\
Scale thickness & $\mathrm{cm}$ & 0.65 & EPA (1993a) \\
Density of scale & $\mathrm{g} / \mathrm{cm}^{3}$ & 2.6 & \\
Worker distance from pipe & $\mathrm{cm}$ & $30^{\mathrm{d}}$ & \\
Worker exposure time & $\mathrm{h} / \mathrm{yr}$ & 2,000 & ICRP (1975) \\
Inhalation rate & $\mathrm{m} 3 / \mathrm{h}$ & 1.2 & NRC (1992) \\
Airborne dust-loading & $\mathrm{g} / \mathrm{m}^{3}$ & $1 \times 10^{-4}$ & EPA (1991) \\
Ingestion rate & $\mathrm{g} / \mathrm{h}$ & $6.25 \times 10^{-3}$ & \\
\hline
\end{tabular}

a Where a reference is not listed, values were selected on the basis of good judgment.

b A sensitivity analysis was conducted on this parameter using a ratio of 1:0.

c A sensitivity analysis was conducted on this parameter using values of $0.5,1$, and $2 \mathrm{~cm}$.

d A sensitivity analysis was conducted on this parameter using values ranging from 0.3 to $1 \mathrm{~m}$. 
TABLE A.2 Assumptions and Input Parameters Used to Model the Storage Vessel Cleaner Scenario

\begin{tabular}{|c|c|c|c|}
\hline Parameter & Units & Value & Reference $^{a}$ \\
\hline $\begin{array}{l}\text { Total radium concentration, } \\
\text { sludge }\end{array}$ & $\mathrm{pCi} / \mathrm{g}$ & 75 (median) & EPA (1993a) \\
\hline Ra-226:Ra-228 & unitless & $3: 1$ & $\begin{array}{l}\text { Baird et al. (1990), } \\
\text { EPA (1993a, } \\
\text { 1993b) }\end{array}$ \\
\hline Source radius & $\mathrm{cm}$ & 185 & \\
\hline Sludge thickness & $\mathrm{cm}$ & 15 & \\
\hline Density of sludge & $\mathrm{g} / \mathrm{cm}^{3}$ & 1.6 & $\begin{array}{l}\text { Baird et al. (1990), } \\
\text { EPA (1993a) }\end{array}$ \\
\hline Worker distance from source & $\mathrm{m}$ & 1 & \\
\hline Worker exposure time & hours per vessel & 10 & \\
\hline Exposure duration & $\mathrm{h} / \mathrm{yr}$ & 100 & \\
\hline
\end{tabular}

a Where a reference is not listed, values were selected on the basis of good judgment. 
TABLE A.3 Assumptions and Input Parameters Used to Model the Storage Yard Scenarios

\begin{tabular}{llll}
\hline \multicolumn{1}{c}{ Parameter } & \multicolumn{1}{c}{ Units } & \multicolumn{1}{c}{ Value } & \multicolumn{1}{c}{ Reference $^{\mathrm{a}}$} \\
\hline Total radium concentrations, scale & $\mathrm{pCi} / \mathrm{g}$ & 480 (median) & EPA (1993a) \\
& & 2,700 (75th-percentile) & \\
Ra-226:Ra-228 & unitless & $3: 1^{\mathrm{b}}$ & Baird et al. (1990), \\
& & & EPA (1993a, 1993b) \\
Length of storage rack & $\mathrm{cm}$ & 915 & \\
Height of storage rack & $\mathrm{cm}$ & 240 & \\
Pipe wall thickness & $\mathrm{cm}$ & $1^{\mathrm{c}}$ & \\
Density of pipe & $\mathrm{g} / \mathrm{cm}^{3}$ & 7.86 & \\
Number of pipes in rack & $\mathrm{unitless}$ & 16 & \\
Scale thickness & $\mathrm{cm}$ & 0.65 & EPA (1993a) \\
Density of scale & $\mathrm{g} / \mathrm{cm}^{3}$ & 2.6 & \\
Worker distance from storage rack & $\mathrm{m}$ & $3^{\mathrm{d}}$ & \\
Worker exposure time & $\mathrm{h} / \mathrm{yr}$ & 2,000 & \\
Resident distance from storage yard & $\mathrm{m}$ & 100 & \\
Resident exposure time & $\mathrm{h} / \mathrm{yr}$ & 8,760 & EPA (1993a) \\
Radon emanation fraction, sludge & unitless & 0.2 & \\
\hline
\end{tabular}

a Where a reference is not listed, values were selected on the basis of good judgment.

b A sensitivity analysis was conducted on this parameter using a ratio of 1:0.

c A sensitivity analysis was conducted on this parameter using values of $0.5,1$, and $2 \mathrm{~cm}$.

d A sensitivity analysis was conducted on this parameter using values ranging from 1 to $12 \mathrm{~m}$.

e The radon emanation for sludge was used because it was assumed that some of the equipment stored in the yard would contain sludge; this value is larger than the emanation fraction for scale and, therefore, more conservative. 
TABLE A.4 Assumptions and Imput Parameters Used to Model the Subsurface Disposal Scenarios

\begin{tabular}{|c|c|c|c|}
\hline Parameter & Units & Value & Reference $^{\mathrm{a}}$ \\
\hline Receptor locations & km & $\begin{array}{l}-3.2^{\mathrm{b}}, 0,0.3,0.8,1.6 \\
3.2,8,16,24,32\end{array}$ & \\
\hline Failure depths & $\mathbf{m}$ & $\begin{array}{l}90 ; 185 ; 275 ; 790 \\
1,280 ; 1,770 ; 2,745 \\
3,230\end{array}$ & \\
\hline Hydraulic conductivity, sandstone & $\mathrm{cm} / \mathrm{s}$ & $3.5 \times 10^{-6} \mathrm{c}$ & $\begin{array}{l}\text { Domenico and } \\
\text { Schwartz (1990) }\end{array}$ \\
\hline Hydraulic conductivity, shale & $\mathrm{cm} / \mathrm{s}$ & $3.5 \times 10^{-10 c}$ & $\begin{array}{l}\text { Domenico and } \\
\text { Schwartz (1990) }\end{array}$ \\
\hline Longitudinal dispersivity & $\mathrm{m}$ & 305 & $\begin{array}{l}\text { Domenico and } \\
\text { Schwartz (1990) }\end{array}$ \\
\hline Transverse dispersivity & m & 30 & $\begin{array}{l}\text { Domenico and } \\
\text { Schwartz (1990) }\end{array}$ \\
\hline Groundwater gradient & unitless & $0.01^{\mathrm{c}}$ & \\
\hline Formation slope & unitless & 0.01 & \\
\hline Slurry volume & bll & 100,000 & \\
\hline Slurry concentration & $\mathrm{pCi} / \mathrm{L}$ & 2,$000 ; 4,000$ & \\
\hline Injection period & days & 4 & \\
\hline Pumping rate of wells & $\mathrm{L} / \mathrm{s}$ & 0.6 & \\
\hline
\end{tabular}

a Where a reference is not listed, values were selected on the basis of good judgment.

b This receptor was located upgradient of the disposal well.

c A sensitivity analysis was conducted on this parameter using values one order of magnitude larger and smaller. 
TABLE A.5 Assumptions and Input Parameters Used to Model the Landspreading with Dilution Scenario

\begin{tabular}{llll}
\hline \multicolumn{1}{c}{ Parameter } & Units & Value & \multicolumn{1}{c}{ Reference $^{\mathrm{a}}$} \\
\hline Total radium concentration in soil & $\mathrm{pCi} / \mathrm{g}$ & $240,30,5$ & \\
Ra-226:Ra-228 & unitless & $3: 1$ & \\
Contaminated area & $\mathrm{m}^{2}$ & 4,050 & \\
Contaminated zone thickness & $\mathrm{cm}$ & 20 & EPA (1993b) \\
Emanation coefficient for scale & unitless & 0.05 & Baird et al. (1990), \\
& & & EPA (1993a), EPA (1993b) \\
Shielding factor & unitless & 0.6 & \\
\hline
\end{tabular}

a Where a reference is not listed, values were selected on the basis of good judgment. 
TABLE A.6 Input Parameters Used to Model the External Pathway for the Smelting Scenarios

\begin{tabular}{|c|c|c|c|c|c|c|}
\hline Recycle Step & Scenario & Source Geometry & $\begin{array}{c}\text { Source radius } \\
(\mathrm{cm})\end{array}$ & $\begin{array}{c}\text { Source thickness } \\
(\mathrm{cm})\end{array}$ & $\begin{array}{l}\text { Distance from } \\
\text { source }(m)\end{array}$ & $\begin{array}{l}\text { Denșity } \\
\left(\mathrm{g} / \mathrm{cm}^{3}\right)\end{array}$ \\
\hline Scrap delivery & $\begin{array}{l}\text { Loader } \\
\text { Truck driver }\end{array}$ & $\begin{array}{l}1 / 2 \text { cylinder } \\
1 / 2 \text { cylinder }\end{array}$ & $\begin{array}{r}127.0 \\
60.0\end{array}$ & $\begin{array}{l}253.0 \\
900.0\end{array}$ & $\begin{array}{l}4.0 \\
2.0\end{array}$ & $\begin{array}{l}3.93 \\
3.93\end{array}$ \\
\hline Scrap processing & Processor & $1 / 2$ cylinder & 60.0 & 60.0 & 2.0 & 5.90 \\
\hline Scrap smelting & $\begin{array}{l}\text { Yard worker } \\
\text { Loader } \\
\text { Operator }\end{array}$ & $\begin{array}{l}1 / 2 \text { cylinder } \\
1 / 2 \text { cylinder } \\
\text { Full cylinder }\end{array}$ & $\begin{array}{l}175.0 \\
139.0 \\
127.0\end{array}$ & $\begin{array}{l}351.0 \\
279.0 \\
253.0\end{array}$ & $\begin{array}{r}10.0 \\
4.0 \\
3.0\end{array}$ & $\begin{array}{l}5.90 \\
5.90 \\
7.86\end{array}$ \\
\hline Industrial products & $\begin{array}{l}\text { Ingot caster } \\
\text { Small objects caster } \\
\text { Slag worker } \\
\text { Loader } \\
\text { Truck driver }\end{array}$ & $\begin{array}{l}\text { Full cylinder } \\
\text { Full cylinder } \\
1 / 2 \text { cylinder } \\
1 / 2 \text { cylinder } \\
\text { Two full cylinders }\end{array}$ & $\begin{array}{r}64.0 \\
201.0 \\
228.0 \\
201.0 \\
64.0\end{array}$ & $\begin{array}{r}100.0 \\
1.0 \\
45.5 \\
100.0 \\
200.0\end{array}$ & $\begin{array}{l}1.5 \\
1.0 \\
1.5 \\
4.0 \\
2.0\end{array}$ & $\begin{array}{l}7.86 \\
7.86 \\
7.86 \\
7.86 \\
7.86\end{array}$ \\
\hline Initial fabrication & $\begin{array}{l}\text { Yard worker } \\
\text { Sheet worker } \\
\text { Coil worker }\end{array}$ & $\begin{array}{l}\text { Five } 1 / 2 \text { cylinders } \\
1 / 2 \text { cylinder } \\
1 / 2 \text { cylinder }\end{array}$ & $\begin{array}{l}201.0 \\
138,0 \\
201.0\end{array}$ & $\begin{array}{r}100.0 \\
0.2 \\
100.0\end{array}$ & $\begin{array}{l}1.5 \\
1.0 \\
1.5\end{array}$ & $\begin{array}{l}7.86 \\
7.86 \\
7.86\end{array}$ \\
\hline Final fabrication & $\begin{array}{l}\text { Sheet worker } \\
\text { Coil worker }\end{array}$ & $\begin{array}{l}1 / 2 \text { cylinder } \\
1 / 2 \text { cylinder }\end{array}$ & $\begin{array}{l}138.0 \\
201.0\end{array}$ & $\begin{array}{r}0.2 \\
100.0\end{array}$ & $\begin{array}{l}1.0 \\
1.5\end{array}$ & $\begin{array}{l}7.86 \\
7.86\end{array}$ \\
\hline Product distribution & $\begin{array}{l}\text { Loader } \\
\text { Truck driver } \\
\text { Sheet worker } \\
\text { Warehouse worker }\end{array}$ & $\begin{array}{l}1 / 2 \text { cylinder } \\
\text { Full cylinder } \\
1 / 2 \text { cylinder } \\
1 / 2 \text { cylinder }\end{array}$ & $\begin{array}{r}201.0 \\
64.0 \\
138.0 \\
138.0\end{array}$ & $\begin{array}{r}100.0 \\
200.0 \\
0.2 \\
1.2\end{array}$ & $\begin{array}{l}4.0 \\
2.0 \\
1.0 \\
6.0\end{array}$ & $\begin{array}{l}7.86 \\
7.86 \\
7.86 \\
7.86\end{array}$ \\
\hline End-use product & $\begin{array}{l}\text { Parking lot (slag) } \\
\text { Automobile } \\
\text { Home furniture } \\
\text { Industry pipe }\end{array}$ & $\begin{array}{l}\text { Full cylinder } \\
\text { Four full cylinders } \\
1 / 2 \text { cylinder } \\
\text { Full cylinder }\end{array}$ & $\begin{array}{r}3,400.0 \\
150.0 \\
110.0 \\
67.0\end{array}$ & $\begin{array}{r}10.0 \\
0.1 \\
0.1 \\
1.3\end{array}$ & $\begin{array}{l}1.0 \\
0.05 \\
0.15 \\
1.0\end{array}$ & $\begin{array}{l}2.7 \\
7.86 \\
7.86 \\
7.86\end{array}$ \\
\hline
\end{tabular}

Source: Nieves et al. (1995). 
TABLE A.7 Input Parameters Used to Model the Internal Pathways for the Smelting Scenarios

\begin{tabular}{|c|c|c|c|c|c|}
\hline Recycle Step & Scenario & $\begin{array}{l}\text { Exposure } \\
\text { Time (h) }\end{array}$ & $\begin{array}{c}\text { Contaminant } \\
\text { Dust Loading } \\
\left(\mathrm{g} / \mathrm{m}^{3}\right)^{\mathrm{a}}\end{array}$ & $\begin{array}{l}\text { Inhalation Rate } \\
\qquad\left(\mathrm{m}^{3} / \mathrm{h}\right)^{\mathrm{a}} \\
\end{array}$ & $\begin{array}{c}\text { Ingestion Rate } \\
(\mathrm{g} / \mathrm{h})^{\mathrm{a}}\end{array}$ \\
\hline Scrap delivery & $\begin{array}{l}\text { Loader } \\
\text { Truck driver }\end{array}$ & $\begin{array}{l}2,000 \\
2,000\end{array}$ & $\begin{array}{l}- \\
-\end{array}$ & - & - \\
\hline Scrap processing & Processor & 2,000 & $1.00 \mathrm{E}-04$ & 1.2 & $6.25 \mathrm{E}-03$ \\
\hline Scrap smelting & $\begin{array}{l}\text { Worker } \\
\text { Loader } \\
\text { Operator }\end{array}$ & $\begin{array}{l}2,000 \\
2,000 \\
2,000\end{array}$ & $\begin{array}{l}1.00 \mathrm{E}-04 \\
1.00 \mathrm{E}-03 \\
1.00 \mathrm{E}-03\end{array}$ & $\begin{array}{l}1.2 \\
1.2 \\
1.2\end{array}$ & $\begin{array}{l}6.25 E-03 \\
6.25 E-03 \\
6.25 E-03\end{array}$ \\
\hline $\begin{array}{l}\text { Industrial } \\
\text { Products }\end{array}$ & $\begin{array}{l}\text { Ingot caster } \\
\text { Small objects caster } \\
\text { Slag worker } \\
\text { Loader } \\
\text { Truck driver }\end{array}$ & $\begin{array}{l}2,000 \\
2,000 \\
2,000 \\
2,000 \\
2,000\end{array}$ & $\begin{array}{l}1.00 \mathrm{E}-03 \\
1.00 \mathrm{E}-03 \\
1.00 \mathrm{E}-03 \\
1.00 \mathrm{E}-08 \\
1.00 \mathrm{E}-08\end{array}$ & $\begin{array}{l}1.2 \\
1.2 \\
1.2 \\
1.2 \\
1.2\end{array}$ & $\begin{array}{c}6.25 \mathrm{E}-03 \\
6.25 \mathrm{E}-03 \\
6.25 \mathrm{E}-03 \\
- \\
-\end{array}$ \\
\hline $\begin{array}{l}\text { Initial } \\
\text { Fabrication }\end{array}$ & $\begin{array}{l}\text { Yard worker } \\
\text { Sheet worker } \\
\text { Coil worker }\end{array}$ & $\begin{array}{l}2,000 \\
2,000 \\
2,000\end{array}$ & $\begin{array}{l}1.00 \mathrm{E}-08 \\
1.00 \mathrm{E}-04 \\
1.00 \mathrm{E}-04\end{array}$ & $\begin{array}{l}1.2 \\
1.2 \\
1.2\end{array}$ & $\begin{array}{c}- \\
6.25 \mathrm{E}-03 \\
6.25 \mathrm{E}-03\end{array}$ \\
\hline Final fabrication & $\begin{array}{l}\text { Sheet worker } \\
\text { Coil worker }\end{array}$ & $\begin{array}{l}2,000 \\
2,000\end{array}$ & $\begin{array}{l}- \\
-\end{array}$ & $\begin{array}{l}- \\
-\end{array}$ & $\begin{array}{l}- \\
-\end{array}$ \\
\hline $\begin{array}{l}\text { Product } \\
\text { Distribution }\end{array}$ & $\begin{array}{l}\text { Loader } \\
\text { Truck driver } \\
\text { Sheet worker } \\
\text { Warehouse worker }\end{array}$ & $\begin{array}{l}2,000 \\
2,000 \\
2,000 \\
2,000\end{array}$ & $\begin{array}{l}- \\
- \\
-\end{array}$ & $\begin{array}{l}- \\
1.2 \\
1.2 \\
1.2\end{array}$ & $\begin{array}{l}- \\
- \\
-\end{array}$ \\
\hline End-use product & $\begin{array}{l}\text { Parking lot } \\
\text { Automobile } \\
\text { Home furniture }\end{array}$ & $\begin{array}{c}62 \\
668 \\
3,650\end{array}$ & $\begin{array}{l}- \\
-\end{array}$ & $\begin{array}{l}1.2 \\
1.2 \\
1.2\end{array}$ & $\begin{array}{l}- \\
-\end{array}$ \\
\hline
\end{tabular}

a A hyphen "-" denotes that the pathway was not used.

Source: Nieves et al. (1995). 


\section{DISTRIBUTION FOR ANL/EAD-2}

Internal

ANL Technical Publications Services

K. Smith (155)

L. Welko (3)

E. Hathaway

\section{External}

U.S. Department of Energy Office of Scientific and Technical Information (12) Manager, U.S. Department of Energy Chicago Field Office

ANL-E Libraries

ANL-W Library 